\title{
Exploring the spatial variation in the fertilizer-nitrogen requirement of wheat within fields
}

Running title: Spatial variation in fertilizer- $N$ requirement

\author{
D.R. KINDRED ${ }^{1 *}$, A.E.MILNE ${ }^{2}$, R.WEBSTER ${ }^{2}$, B.P.MARCHANT ${ }^{3}$ AND R. \\ SYLVESTER-BRADLEY ${ }^{1}$
}

${ }^{1} A D A S$, Boxworth, Cambridge CB23 4NN, UK

${ }^{2}$ Rothamsted Research, Harpenden, Hertfordshire AL5 2JQ, UK

${ }^{3}$ British Geological Survey, Keyworth, Nottingham NG12 5GG, UK

(MS received 5 June 2013, revised 16 September 2013, accepted TBC October 2013)

\section{SUMMARY}

The fertilizer-nitrogen requirement for wheat grown in the United Kingdom varies from field to field. Differences in soil type, climate and cropping history result in differences in (i) the crops' demands for nitrogen (N), (ii) the supply of $\mathrm{N}$ from the soil (SNS) and (iii) the recovery of fertilizer by the crops. These three components generally form the basis of systems for $\mathrm{N}$ recommendation. Three field experiments were set out to investigate the variation of the $\mathrm{N}$ requirement for wheat within fields and to explore the importance of variation in the crops' demands for N, SNS and fertilizer recovery in explaining the differences in the economic optima for N. The nitrogen optima were found to vary by $>100 \mathrm{~kg} \mathrm{~N} / \mathrm{ha}$ at two of the sites. At the other site the yield response to $\mathrm{N}$ was small. Yields at the optimum rate of nitrogen varied spatially by c. $4 \mathrm{t} / \mathrm{ha}$ at each site. Soil $\mathrm{N}$ supply, which was estimated by the unfertilized crops' harvested $\mathrm{N}$, varied spatially by 120,75 and $60 \mathrm{~kg} / \mathrm{ha}$ in the three

\footnotetext{
* To whom all correspondence should be addressed. Email: daniel.kindred@adas.co.uk
} 
experiments. Fertilizer recovery varied spatially from $30 \%$ to $>100 \%$ at each of the sites. There were clear relationships between SNS and N optima at all three sites. The expected relationship between the crop's demand for $\mathrm{N}$ and $\mathrm{N}$ optima was evident at only one of the three sites. There was no consistent relationship between $\mathrm{N}$ recovery and $\mathrm{N}$ optima. A consistent relationship emerged, however, between optimal yield and soil $\mathrm{N}$ supply; areas with a greater yield potential tended to also supply more $\mathrm{N}$ from the soil. This moderated the expected impact of SNS and the crop's demand for $\mathrm{N}$ on the $\mathrm{N}$ optima.

\section{INTRODUCTION}

Modern varieties of wheat grown in temperate regions require the application of nitrogen $(\mathrm{N})$ fertilizer to realize their yield potential. The fertilizer can increase both yields and profitability for farmers. However, it not only increases agricultural yields but can also damage the environment, both globally and locally (Sutton et al. 2011). Excess nitrogen can be transformed to nitrous oxide and emitted into the atmosphere, and leaching of nitrate can cause eutrophication in lakes and rivers. Nitrogen fertilizer is estimated to be responsible for c. 0.70 of the emissions of greenhouse gas from wheat production (Berry et al. 2010). So, both farmers and governments have an interest in ensuring that fertilizer nitrogen is applied to maximum efficiency. There are guidelines and decision-support systems to help farmers to decide how much fertilizer to apply, but these are disappointingly ineffective (Sylvester-Bradley et al. 2008; Kindred et al. 2012).

For many years, rates of fertilizer were determined for individual fields, but modern technology and machines enable farmers to vary their applications of fertilizer 
at as fine a resolution as $10 \times 10 \mathrm{~m}$. Agronomists have therefore sought to estimate the nitrogen requirement at the same spatial resolution (Heege et al. 2008).

Since the 1970s the optimum applications of fertilizer $\mathrm{N}$ for individual experiments have been determined empirically from data on the response of the yield to a range of rates of fertilizer $\mathrm{N}$ (including zero). This has been achieved by fitting response curves to yield data as functions of applied nitrogen, and then interpolating the point at which profit to the farmer is maximized (Boyd et al. 1976). This point is the optimum $\mathrm{N}$ requirement $\left(N_{\mathrm{opt}}\right)$. The point depends on two factors external to each crop experiment, namely the choice of fitted curve and the relative price of grain to fertilizer $\mathrm{N}$ (the break-even ratio: BER). The BER describes the weight of grain required to pay for a given weight of fertilizer $\mathrm{N}$, and is typically around 5:1, but it has varied between 2:1 and 9:1 in recent decades (Sylvester-Bradley \& Kindred 2009). The economic optimum is the point on the response curve at which the slope equals the BER; i.e. the point at which increasing the fertilizer $\mathrm{N}$ applied by 1 unit would not increase grain yields sufficiently to pay for the cost of that fertilizer.

National recommendations for nitrogen fertilizer are based on the accumulated evidence of numerous experiments on nitrogen response (Defra 2010). Implicit in these recommendations are three underlying principles, as follows.

1. Crop $N$ demand (CND). The crop demands nitrogen from the soil so that it can create enough photosynthetic material (i.e. leaves and stem) to maximize its production of dry matter (Grindlay 1997; Lemaire et al. 2007). It also demands nitrogen to satisfy protein deposition in the grain (Pask et al. 2012). In wheat crops yielding $>9 \mathrm{t} / \mathrm{ha}$ with grain protein of $110 \mathrm{~g} / \mathrm{kg}$ dry matter, the demand for nitrogen for grain protein tends to exceed that for photosynthesis. 
2. Soil N Supply (SNS). Nitrogen derived from the soil comes from the residues of previous crops and the mineralization of organic matter (plus that from atmospheric deposition). It tends to be the most variable component of the nitrogen requirement (Kindred et al. 2012), and its prediction is the focus of most recommendation systems.

3. Fertilizer $N$ recovery (FNR). The difference between the CND and the SNS is the nitrogen that needs to be supplied in the fertilizer for the crop to fulfil its potential. Fertilizer $\mathrm{N}$ is usually recovered with much less than $100 \%$ efficiency. The efficiency, expressed as a percentage, is known as the fertilizer $\mathrm{N}$ recovery and is on average $c .60 \%$ (Bloom et al. 1988). Thus the fertilizer $\mathrm{N}$ needed to fulfil the crop's demand (the fertilizer $\mathrm{N}$ requirement, $\mathrm{F}$ ) is given by

$$
F=\frac{\mathrm{CND}-\mathrm{SN} \varsigma}{\mathrm{FNR}}
$$

The crop's demand for $\mathrm{N}$ and the soil $\mathrm{N}$ supply can be quantified from crop measurements. The nitrogen taken up by the crop (crop $\mathrm{N}$ uptake) increases almost linearly with the rate of $\mathrm{N}$ applied to a maximum, which represents the crop $\mathrm{N}$ demand (Bloom et al. 1988; Sylvester-Bradley \& Kindred 2009). Adding more fertilizer $\mathrm{N}$ past this point will not result in an increase in the amount of $\mathrm{N}$ taken up by the crop. The nitrogen taken up by this fertilized crop can be used to estimate the crop $\mathrm{N}$ demand. The nitrogen taken up by an unfertilized crop, termed 'the harvested soil $\mathrm{N}$ supply', can be used as an estimate of the soil $\mathrm{N}$ supply.

Fertilizer $\mathrm{N}$ recovery, which is the proportion of the added fertilizer taken up by the crop, is the most problematic of the components to calculate. Without adding ${ }^{15} \mathrm{~N}$-labelled fertilizer, however, one cannot distinguish $\mathrm{N}$ in the crop derived from the 
fertilizer from that from the soil. Even with the use of labelled fertilizer the interchangeability of soil $\mathrm{N}$ and fertilizer $\mathrm{N}$ makes interpretation difficult. Fertilizer recovery for a given rate of applied nitrogen is therefore normally given as the apparent fertilizer recovery (AFR); it is calculated from the $\mathrm{N}$ taken up by the crop with $\mathrm{N}$ applied minus crop $\mathrm{N}$ uptake with nil-N (harvested soil $\mathrm{N}$ supply) divided by the rate of applied nitrogen (Bloom et al. 1988).

The AFR evidently depends on estimates of soil $\mathrm{N}$ supply, and it is implicitly assumed that recovery of soil $\mathrm{N}$ remains constant as fertilizer $\mathrm{N}$ is applied. There is also the difficulty that the fertilizer recovery depends on the quantity of $\mathrm{N}$ applied. It is generally found that the response of the crop to initial additions of nitrogen is linear and then declines until it is zero once the crop's demand for $\mathrm{N}$ has been satisfied (beyond this point there is no increase in $\mathrm{N}$ uptake no matter how much nitrogen is applied).

Crop $\mathrm{N}$ demand, soil $\mathrm{N}$ supply and AFR can be estimated by fitting a model to data on $\mathrm{N}$ uptake from experiments on nitrogen response. The model most commonly used is a split-line model, with the slope of the second line constrained to zero, (Kindred et al. 2012; Sylvester-Bradley et al. 2013):

$$
z=\alpha+\beta N \text { when } \alpha+\beta N<\gamma
$$

$z=\gamma$ otherwise 
Where $z$ is the crop $\mathrm{N}$ uptake, $\mathrm{N}$ is the fertilizer $\mathrm{N}$ applied. The parameters $\alpha, \beta$ and $\gamma$ represent soil $\mathrm{N}$ supply, AFR and crop $\mathrm{N}$ demand, respectively.

Kindred et al. (2012) explored the components of the nitrogen requirement at a national scale using data from earlier experiments on nitrogen responses. The current study, however, is concerned with the variation in nitrogen requirement and its underlying components within fields; the local response to nitrogen therefore had to be quantified. In other studies the investigators (Lark \& Wheeler 2003; Pringle et al. 2004; Bishop \& Lark 2006) have taken a similar approach. The approach offers the opportunity to understand the variation in nitrogen requirement and its causes, without the normal confounding differences in management, weather, variety, previous crop history, etc.

'Checkerboard' experiments (described below) enabled the spatial variation in $\mathrm{N}$ requirements to be examined. The variation in soil $\mathrm{N}$ supply, crop $\mathrm{N}$ demand and AFR were examined along with their relationships with one another and their relationship to the optimum fertilizer application $\left(N_{\text {opt }}\right)$ at three sites in two seasons. Thus several hypotheses relating to fertilizer recommendations could be explored, as follows.

1. If a crop has a large demand for nitrogen then

(a) either it warrants a larger application of fertilizer $\mathrm{N}$, or

(b) the crop $\mathrm{N}$ demand is positively related to fertilizer recovery or soil $\mathrm{N}$ supply, thereby tempering the extra requirement for nitrogen.

2. As soil $\mathrm{N}$ supply increases so

(a) the optimum $\mathrm{N}$ requirement diminishes in direct proportion modified by the recovery of fertilizer $\mathrm{N}$, or 
(b) the recovery of soil $\mathrm{N}$ supply reduces (Knight et al. 2008) and so tempers the effect of differences in soil $\mathrm{N}$ supply on $\mathrm{N}$ requirements.

3. The protein content of grain remains fairly constant when optimum $\mathrm{N}$ is applied. This means that measurements of protein can indicate successful fertilizer management (Sylvester-Bradley \& Clarke 2009).

\section{MATERIALS AND METHODS}

The experimental designs

The experiments were laid out on three commercial fields in England with designs shown in Fig. 1. These experiments are referred to as F1, F2 and B1. Two of the fields, F1 and F2, were on Hall Farm at Flawborough, Nottinghamshire $\left(52^{\circ} 58^{\prime} \mathrm{N}, 0^{\circ}\right.$ $\left.50^{\prime} \mathrm{W}\right)$. The third, B1, was on Signet Hill Farm at Burford, Oxfordshire $\left(51^{\circ} 48^{\prime} \mathrm{N}, 1^{\circ}\right.$

$40^{\prime} \mathrm{W}$ ). In each experiment winter wheat was grown with cultivars Alchemy (on F1), Duxford (on F2) and Solstice (on B1). The HGCA Recommended List (HGCA 2013) shows the varieties to have similar yield potential $(98,100$ and $96 \%$ of a control, respectively). Alchemy and Duxford are feed varieties, whereas Solstice is a milling variety with a higher protein content $(111,108$ and $118 \mathrm{~g} / \mathrm{kg}$ dry matter respectively), which would be expected to need as much as $20 \mathrm{~kg} / \mathrm{ha}$ more fertilizer N (SylvesterBradley 2009).

The soil at Flawborough is dominantly clay loam. In field F1 it is of the Evesham, Worcester and Fladbury series (Table 1). In Field F2, adjacent to field F1, the soil is also clay of the Worcester and Fladbury series. The soil in Field B1 is typical of large areas on the Jurassic limestones, known locally as 'Cotswold brash'. Most is fairly thin brown calcareous clay loam containing numerous limestone fragments (Elmton series, Table 1). The experiment lies across the head of a dry 
valley in which the soil is considerably deeper (Aberford series, Table 1). The soil series across each experiment are shown in Figs $2 a(\mathrm{~F} 1), 3 a(\mathrm{~F} 2), 4 a(\mathrm{~B} 1)$.

Table 2 summarizes the weather at Flawborough and Burford during the seasons that the experiments were done.

The basic design of the experiments was that of a checkerboard (Pringle et al. 2004) of contiguous square plots, $c .10 \mathrm{~m}$ on each side. The plots were grouped into sets of four, and in each set four levels of $\mathrm{N}$, one of which was nil, were applied in a fixed pattern (Fig. 1a). The actual amounts applied varied according to the judged requirement of the crop after the mineral $\mathrm{N}$ in the soil had been measured in the spring. Soil samples on which to determine mineral $\mathrm{N}$ were taken from at least 15 positions in each experiment. Sample points were chosen to cover the expected variation in the field. Average soil mineral $\mathrm{N}$ results were $36 \mathrm{~kg} / \mathrm{ha}$ at F1 (range 24-56 $\mathrm{kg} / \mathrm{ha}$, standard deviation $8.3 \mathrm{~kg} / \mathrm{ha}$ ), $108 \mathrm{~kg} / \mathrm{ha}$ at F2 (range $63-157 \mathrm{~kg} / \mathrm{ha}$, standard deviation $30 \mathrm{~kg} / \mathrm{ha}$ ) and $63 \mathrm{~kg} / \mathrm{ha}$ at B1 (range 34-104 kg/ha, standard deviation 18.9 $\mathrm{kg} / \mathrm{ha}$ ). Therefore on fields F1 and B1, the plots were fertilized with either 0, 120, 240 or $360 \mathrm{~kg} \mathrm{~N} / \mathrm{ha}$ and on field F2, where the optimum was expected to be less, the plots were fertilized with either $0,100,200$ or $300 \mathrm{~kg} \mathrm{~N} / \mathrm{ha}$. In each experiment fertilizer was applied as a liquid (urea and ammonium nitrate) with a conventional farm sprayer. At each site the total amount of fertilizer was applied in two equal portions, one in March and one in April. On each application date the sprayer crossed the field twice, with the second set of passes perpendicular to the first. On the first pass, half the boom applied no $\mathrm{N}(\mathrm{N} 0)$ and the other half applied $\mathrm{N}$ at rate $1(\mathrm{~N} 1)$. On the second perpendicular pass, again half the boom applied no $\mathrm{N}$ and the other half applied $\mathrm{N}$ at rate $2(\mathrm{~N} 2)$. This resulted in four rates of $\mathrm{N}$ : rates $0(\mathrm{~N} 0+\mathrm{N} 0), 1(\mathrm{~N} 1+\mathrm{N} 0), 2(\mathrm{~N} 0+$ $\mathrm{N} 2)$ and $3(\mathrm{~N} 1+\mathrm{N} 2)$. 
The experiment on field F1 was carried out in the 2010/11 season and was imposed on the field in a rectangular strip of $12 \times 44=528$ plots, each $10 \times 10 \mathrm{~m}$ (Fig. 1). The other two experiments were conducted in season 2011/12 with an experimental protocol and design similar to that used in field F1. In field F2 the experimental plots were in a rectangular strip of $12 \times 36=432$ plots, each $9 \times 9 \mathrm{~m}$.

To capture the full variation in field B1 a rectangular strip of $16 \times 22$ plots, $11 \times 11 \mathrm{~m}$ was imposed on the field with an additional two strips of 13 and 11 plots down one side (Fig. 4a), giving a total of 376 plots.

In all three experiments the wheat was harvested with a plot combine harvester and grain yield was measured. To eliminate any effect of harvesting direction being confounded with treatment two cuts were taken in opposite directions and the yields were averaged. The moisture content of each sample of grain was measured with a Dickey-John moisture meter, and the measured yields were corrected to $850 \mathrm{~g} / \mathrm{kg}$ dry matter. Protein (as g/kg dry matter) was measured on one sample of grain from each plot with a FOSS Infratec NIR analyser. Before harvest, grab samples of $c .100$ shoots were taken from each plot. The shoots were counted, and the ears were separated from the straw, dried and weighed. The ears were then threshed, and grain was weighed. From these measurements the harvest index for each plot was estimated by dividing the grain dry matter per shoot by the total dry matter per shoot, and the proportion of $\mathrm{N}$ in the straw was determined by the Dumas method. Using these measurements together with the combine grain yield and grain protein, the $\mathrm{N}$ taken up in the grain was estimated by multiplying the grain yield by the proportion of protein in the grain and dividing by 5.7 , which is the conversion factor in wheat for converting grain $\mathrm{N}$ $(\mathrm{g} / \mathrm{kg})$ to grain protein content $(\mathrm{g} / \mathrm{kg})$. 
The $\mathrm{N}$ harvest index was estimated by division of the grain $\mathrm{N}$ per shoot by the total $\mathrm{N}$ per shoot. Finally, total $\mathrm{N}$ uptake was estimated by dividing the $\mathrm{N}$ in the grain by the $\mathrm{N}$ harvest index.

Calculating the optimum $\mathrm{N}$ requirement

Response models were fitted to the local yield measurements from within windows of size $3 \times 3$ plots. These were used to estimate the optimum $\mathrm{N}\left(N_{\text {opt }}\right)$ for each plot. It was assumed that the fitted response model represents the behaviour of the central plot, i.e. a response for a given plot was based on the measurement from the plot itself and the measurements from the neighbouring plots. The fitted responses for plots that lay at the edge of the experiment were necessarily based on fewer measurements. The exponential equation was chosen as the model:

$$
y_{p}=a_{p}+b_{p} R_{p}^{N} \quad \text { for } p=1,2, \ldots, n
$$

Here $y_{p}$ is yield (t/ha), $N$ is applied $N(\mathrm{~kg} / \mathrm{ha}), n$ is the number of plots and $a_{p}, b_{p}$ and $R_{p}$ are parameters fitted to the data assigned to plot $p$. This model is used widely, but sometimes it is generalized by addition of an extra term $c_{p} N$, where $c_{p}$ is another parameter. This generalization allows for loss of yield at larger rates of $N$, which sometimes occurs because of lodging, increased susceptibility to disease, greater respiration or less efficient photosynthesis. To avoid over-fitting and because the yield at the largest rate of fertilizer ( 360 or $300 \mathrm{~kg} / \mathrm{ha}$ ) was never much less than the yield at the 240 or $200 \mathrm{~kg} / \mathrm{ha}$ rate, the simpler model was chosen.

In addition, because the model was fitted to few data, the parameter $R_{p}$ was kept constant for any one field (denoted $R$ ). Fixing this parameter is common practice 
in the analysis of experiments on the response of crops to nitrogen in Britain (Lark \& Wheeler 2003) and has little effect on the goodness of fit. The yield response model was fitted with the GenStat directive FITNONLINEAR (Payne et al. 2011), and this gave estimates for the parameters $a_{p}, b_{p}$ and $R$ for $p=1,2, \ldots, n$ with associated standard errors.

Given a yield response function and prices for $\mathrm{N}$ fertilizer and wheat grain, the optimum rate of $\mathrm{N}$ fertilizer can be calculated as:

$$
N_{\mathrm{opt}}=\ln (R) \ln \left\{\frac{\mathrm{BER} \times \ln (R)}{1000 b_{p}}\right\} \quad \text { for } p=1,2, \ldots, n
$$

A BER of 7:1 based on a wheat price of $£ 150$ per $t$ and a price for $N$ fertilizer of $£ 1.05$ per $\mathrm{kg}$ was used, and the GenStat directive RFUNCTION was used to estimate the $\mathrm{N}$ optimum for each plot and the associated standard error.

Identifying the components of the requirement for fertilizer $\mathrm{N}$

To estimate the three components of the fertilizer-N requirement, $F$ in Eqn (1), the local response in $\mathrm{N}$ taken up by the crop to the application of $\mathrm{N}$ fertilizer first had to be estimated. A split line model was fitted, given in Eqn (5) below, to measurements of $\mathrm{N}$ taken up in the crop from within local windows of size $3 \times 3$ plots, and it was assumed that the fitted response model represents the behaviour of the central plot:

$$
\begin{gathered}
z_{p}=\alpha_{p}+\beta_{p} N \text { when } \alpha_{p}+\beta_{p} N<\gamma_{p} \\
z_{p}=\gamma_{p} \text { otherwise; for } p=1,2, \ldots, n
\end{gathered}
$$


Here $z_{p}$ is the crop $\mathrm{N}$ uptake on plot $p, N$ is applied $\mathrm{N}(\mathrm{kg} / \mathrm{ha}), n$ is the number of plots, and $\alpha_{p}, \beta_{p}$ and $\gamma_{p}$ are parameters, fitted to the data assigned to plot $p$. Each of the parameters represents a component of the fertilizer $\mathrm{N}$ requirement of the crop: $\alpha_{p}$ is the soil $\mathrm{N}$ supply on plot $p, \beta_{p}$ is the AFR on plot $p$, and $\gamma_{p}$ is the crop $\mathrm{N}$ demand on that plot.

The relationship between the components of the fertilizer $\mathrm{N}$ requirement and optimum $\mathrm{N}$

Each of the components of fertilizer $\mathrm{N}$ requirement was treated as an explanatory variable for the observed response in optimum $\mathrm{N}$. Where there appeared to be a relationship between optimum $\mathrm{N}$ and the explanatory variable boundary-line models were fitted. The boundary-line model, first proposed by Webb (1972), describes sets of data in which one variable (the explanatory variable) appears to limit the response of the other (the response variable). The concept is that there is some upper limit (or boundary) to the value of the response variable at any given value of the independent variable so that values larger than the boundary are impossible (apart from error). Data points lying below the boundary are limited by other factors.

In the current context, optimum $\mathrm{N}$ is the response variable, and one of the components of $\mathrm{N}$ requirement (e.g. crop $\mathrm{N}$ demand) is the explanatory variable. The boundary line describes the relationship between the two. Scatter below the boundary line results from factors other than the explanatory variable having a substantial limiting influence on optimum N. If no other variable substantially limits the response variable, however, then the boundary line will go through the middle of the scatter more akin to a regression model. 
The method of Milne et al. (2006) was used to fit boundary-line models which effectively describe censored bivariate probability distributions. The censor in the distribution is the boundary line, and a parameter of variation quantifies the error around the boundary line. The censored bivariate distribution is fitted to the data by maximum likelihood. Akaike's information criterion (AIC) (Akaike 1973) was used to assess whether the boundary line model represented the relationship better than a bivariate normal model. The AIC allows the comparison of models based on a compromise between parsimony and goodness of fit (which usually improves with increasing numbers of parameters). The AIC for any given set of data can be represented by

$$
A I C=-2 \ln M+2 Q
$$

where $M$ is the maximum likelihood value and ${ }_{Q}$ is the number of parameters in the model. When comparing two or more models with the same number of parameters one will favour the one with the largest likelihood; that model will also have the smallest AIC. If models have different numbers of parameters then the one with the smallest AIC is the most appropriate, regardless of the size of M. Milne et al. (2006) expanded on this in the context of boundary-line fitting. In the instances where the boundary-line model was not the best, linear regression models were fitted to the data and soil type was treated as a factor to see if there was any evidence that the relationship changes with differences in soil type.

Crop $N$ demand 
A positive response was expected between the demand for $\mathrm{N}$ by the crop and the optimum application of $\mathrm{N}$, because where the demand is smaller the optimum for applied $\mathrm{N}$ will also be smaller. To investigate the relationship between crop $\mathrm{N}$ demand and optimum $\mathrm{N}$, optimum $\mathrm{N}$ was plotted against the crop $\mathrm{N}$ uptake obtained at the maximum fertilizer rate (i.e. $360 \mathrm{~kg} \mathrm{~N} /$ ha for field F1, $300 \mathrm{~kg} \mathrm{~N} / \mathrm{ha}$ for field F2 and $360 \mathrm{~kg} \mathrm{~N} / \mathrm{ha}$ for field $\mathrm{B} 1$ ). These rates of fertilizer $\mathrm{N}$ span the maximum value attainable by the crop.

\section{Soil N supply}

A negative relationship between $\mathrm{N}$ supply from the soil and optimum $\mathrm{N}$ was expected. To confirm, optimum $\mathrm{N}$ was plotted against the harvested soil $\mathrm{N}$ supply.

\section{Fertilizer $N$ recovery}

Fertilizer $\mathrm{N}$ recovery was expected to be negatively related to optimum $\mathrm{N}$, because optimum $\mathrm{N}$ should decrease with the increasing efficiency of use of the fertilizer. No direct measurement that related to fertilizer $\mathrm{N}$ recovery were available, and so instead the model in Eqn (5) was fitted to provide an estimate of AFR, the apparent fertilizer recovery.

\section{RESULTS}

All three sites showed large variation in grain yield (Table 3), with yields at one $\mathrm{N}$ level varying by $>4.5 \mathrm{t} / \mathrm{ha}$ at each site. At sites $\mathrm{F} 1$ and $\mathrm{B} 1$ the unfertilized yields varied even more. The application of $\mathrm{N}$ fertilizer increased the average yield by 3.8 $\mathrm{t} / \mathrm{ha}$ at $\mathrm{F} 1$ and by more than $5 \mathrm{t} / \mathrm{ha}$ at $\mathrm{B} 1$, but at site $\mathrm{F} 2$ fertilizer increased the average yield by only $0.3 \mathrm{t} / \mathrm{ha}$. 
Grain protein content at one $\mathrm{N}$ level varied by $c .2 \%$ at site $\mathrm{F} 1$ and by $>3 \%$ (on a dry-matter basis) at sites F2 and B1 (Table 4). The application of $\mathrm{N}$ fertilizer increased the average grain protein content at each site, by $>4 \%$ at site $\mathrm{F} 1,2.4 \%$ at site F2 and 3.4\% at site B1. Notably, despite the small response of yield to the applied $\mathrm{N}$ in field $\mathrm{F} 2$, the increase in grain protein in response to applied $\mathrm{N}$ was similar to those in the other two fields.

Table 5 summarizes the crop's uptake of $\mathrm{N}$ for each of the treatments in each of the fields. The average amount of $\mathrm{N}$ in the harvested crop on the unfertilized plots at site F2 was larger than the averages at the other two sites. The response to applied $\mathrm{N}$ was small at site $\mathrm{F} 2$, however, and the average at the maximum rate $(170 \mathrm{~kg} / \mathrm{ha})$ was much smaller than the average at sites F1 and B1 $(248$ and $233 \mathrm{~kg} / \mathrm{ha}$ respectively).

\section{Estimating optimum $\mathrm{N}$}

The fitted $\mathrm{N}$ optima for the sites are shown in Figs $2 b$ (F1), $3 b$ (F2) and $4 b(\mathrm{~B} 1)$, and the associated standard errors are shown in Figs $2 c$ (F1), $3 c$ (F2) and $4 c$ (B1). Standard errors can be used to indicate the relative uncertainties of the parameter estimates. Here, however, the calculated standard errors will be somewhat biased because the surveys were systematic rather than probabilistic. Where standard errors are large, however, there is strong evidence that the parameter estimates are uncertain. Table 6 summarizes the estimates of optimum N. One of the plots in F1 (row 1, column 1) and three of the plots in B1 (row 14, columns 23 and 24, and row 6, column 23) were over-fertilized, so a reliable value for the optimum could not be estimated for them. Nor could an N response curve be fitted for large areas of site F2,

and so again an optimum could not be determined. Therefore the ${ }^{R}$ parameter was 
fixed at 0.995 . This value is commonly used in modelling the responses of wheat to $\mathrm{N}$ in Britain (Sylvester-Bradley et al. 2013) and similar to that found in the other two trials of the current study.

The range in optimum $\mathrm{N}$ obtained from the fitting was substantial at all sites (Table 6), but it was largest at sites F1 and B1 where it exceeded $100 \mathrm{~kg} / \mathrm{ha}$. At site F2, where the soil contained more mineral $\mathrm{N}$, the standard errors for optimum $\mathrm{N}$ were large and the estimates of the $\mathrm{N}$ optima were very uncertain there.

There was an apparent relationship between soil series and $\mathrm{N}$ optima at sites F1 and F2. At site F1, the optima on the Evesham series were larger than those of the neighbouring Worcester-Evesham intergrade, as is evident on right-hand sides of Fig. $2 a$ and $b$. At site F2, the optima that were $>$ zero tended to be on the Worcester series (Fig. $5 b$ ). There was no evident relation between optimum $\mathrm{N}$ and soil series at site B1.

The components of the fertilizer $\mathrm{N}$ requirement

\section{Field F1}

Figure 2 shows the estimates of crop $\mathrm{N}$ demand $(d)$, soil $\mathrm{N}$ supply $(e)$, and AFR $(f)$ derived by fitting Eqn (5) to the data. The spatial variation in crop $\mathrm{N}$ demand and soil $\mathrm{N}$ supply are broadly similar. Where the demand is large the supply tends to be large also, and vice versa. The map of AFR shows that generally the greatest values occur on the Fladbury and Evesham soils. Of the three components, the map of soil $\mathrm{N}$ supply most closely resembles the map of optimum $\mathrm{N}$, suggesting that soil $\mathrm{N}$ supply influences optimum $\mathrm{N}$ the most.

\section{Field F2}


Similarly, Fig. 3 shows the estimates of crop $\mathrm{N}$ demand (d), soil $\mathrm{N}$ supply (e) and AFR $(f)$ derived by fitting Eqn (5) to the data from field F2. Figure $3 d$ shows that the largest demand for nitrogen was on the Worcester soil, which was where the positive values of optimum $\mathrm{N}$ were concentrated. Across the Worcester soil there was some similarity between the map of $\mathrm{N}$ supply and the map of optimum $\mathrm{N}$ across this soil. The spatial variation in crop $\mathrm{N}$ demand and AFR are broadly similar. Where crop $\mathrm{N}$ demand was large AFR tends to be small, and vice versa.

\section{Field B1}

Figure 4 shows the estimates of crop $\mathrm{N}$ demand $(d)$, soil $\mathrm{N}$ supply $(e)$ and AFR $(f)$ derived by the fitting of Eqn (5) to the data of field B1. Financial constraints meant that only 227 of the 376 grab samples could be analysed for $\mathrm{N}$ content and harvest index; and so the model could not be fitted nor the components for $\mathrm{N}$ requirement be estimated for all plots. In the figures, the plots for which no estimates were available are left white. The crop $\mathrm{N}$ demand was largest on the Aberford soil. Not surprisingly, the larger values for $\mathrm{N}$ supply were mainly in the dry valley where the soil is deepest. Visually there was little coherent spatial pattern in the estimates for AFR (Fig. 4f); neighbouring plots tended to have similar values whereas ones further away differed more.

The relationship between Crop $\mathrm{N}$ demand and optimum $\mathrm{N}$

Crop $\mathrm{N}$ demand was estimated from crop $\mathrm{N}$ uptake as described above. Figure 5 shows optimum $\mathrm{N}$ plotted against crop $\mathrm{N}$ uptake with (a) $360 \mathrm{~kg} \mathrm{~N} / \mathrm{ha}$ in field F1, (b) $300 \mathrm{~kg} \mathrm{~N} / \mathrm{ha}$ in field F2, and (c) $360 \mathrm{~kg} \mathrm{~N} / \mathrm{ha}$ in field B1. Evidently the data displayed in Fig. $5 a$ conforms to a boundary-line model, and this was supported by the AIC. 
Two boundary-line models were considered. The first describes all of the data, and the second has a separate model for the Fladbury series (which appears to have a boundary higher in the scatter than the rest of the data). The AIC indicates that a separate boundary line suits the Fladbury data better. The modelled boundary lines are shown on the figure, and the parameters are listed in Table 7. Figure $5 a$ shows most of the scatter to lie below the fitted boundary lines and that on most of the plots the optima were limited by factors other than the demand for $\mathrm{N}$ by the crop.

The data in Fig. $5 b$ show little relationship between the variables, and so a model was not fitted. It is clear, however, that the optimum $\mathrm{N}$ was rarely larger than zero on the Fladbury soil.

There is an apparent boundary in the data plotted in Fig. $5 c$. According to the AIC, however, a bivariate normal model described the data better than a boundaryline model. An accumulated analysis of variance showed that separate models should not be fitted for each soil type. The fitted model is plotted on Fig. $5 c$, and Table 7 reports the parameter values, together with $R^{2}$.

The relationship between Soil nitrogen supply and optimum N Soil nitrogen supply was estimated from crop N uptake as described above. Figure 6 shows optimum $\mathrm{N}$ (in $\mathrm{kg} / \mathrm{ha}$ ) plotted against crop $\mathrm{N}$ uptake where no fertilizer $\mathrm{N}$ was applied (harvested soil N supply) for (a) field F1, $(b)$ field F2, and (c) field B1. The fitted models are also shown, and their parameters are reported in Tables 6 and 7. In each case the AIC supported a boundary-line model over a bivariate normal model. For field F1 (Fig. 6a), the AIC suggested a separate boundary-line model for the data from the Fladbury soil. Most of the scatter lies around the fitted boundary lines, showing that factors other than soil $\mathrm{N}$ supply have little effect on optimum $\mathrm{N}$. The 
boundary-line analysis of the data from site F2 supported the observation that on the Worcester soil the supply of $\mathrm{N}$ from the soil was important in determining the $\mathrm{N}$ optima. For field B1, the measurements made on the Aberford soil tend to cluster around the boundary, suggesting that on this soil, factors other than soil $\mathrm{N}$ supply did not substantially limit optimum $\mathrm{N}$.

The relationship between apparent fertilizer recovery and optimum $\mathrm{N}$ The model in Eqn 5 was fitted to the data to provide estimates of the apparent fertilizer recovery. Figure 7 shows optimum $\mathrm{N}$ plotted against estimated apparent fertilizer recovery (AFR) for each field. There were no direct measurements of AFR, only model estimates, and so one must be cautious when interpreting the results. According to the AICs the data in Fig. $7 a$ conformed to a boundary-line model with a separate boundary line to describe the data from the Fladbury soil. The boundary lines are shown on the figure, and the parameters are given in Table 7. The relationship between AFR and optimum $\mathrm{N}$ was expected to be negative, but here it was positive. This could be an artefact of the model fitting or a result of an interaction between the soil N supply and the AFR.

There was no evident relationship between optimum N and AFR at site F2 or site $\mathrm{B} 1$, Figs $7 b$ and $7 c$.

\section{DISCUSSION}

At all three sites, the optimum fertilizer dressings varied substantially across the fields (typically by c. $100 \mathrm{~kg} \mathrm{~N} / \mathrm{ha}$ ). Lark \& Wheeler (2003) found a similar result for a field in southern England. At site F2, the poor response in yield to applied fertilizer resulted in large standard errors which means the estimates of the $\mathrm{N}$ optima are only 
rough, but one can be sure that the $\mathrm{N}$ requirements there are small $(<100 \mathrm{~kg} \mathrm{~N} / \mathrm{ha})$. Experiments showing little or no yield response to fertilizer $\mathrm{N}$ are fairly common in the UK. For example, Sylvester-Bradley et al. (2008) found that winter wheat did not respond to added $\mathrm{N}$ in six out of 30 experiments; they were usually able to attribute this lack of response to a large supply of nitrogen from the soil. A similar explanation can account for the current observations at site F2, where there was a large amount of mineral $\mathrm{N}$ in the soil $(60-140 \mathrm{~kg} / \mathrm{ha})$.

The response to fertilizer $\mathrm{N}$, however, can depend on the weather, and the poor response at Flawborough in 2011 was probably caused by drought. There was little rain there during March, April and May compared with the long-term average of $160.5 \mathrm{~mm}$. This lack of rain severely limited the uptake of fertilizer $\mathrm{N}$ and limited crop growth and tillering. The warm, dry conditions increased the likelihood of loss of fertilizer $\mathrm{N}$ through volatilization of ammonia. The drought is likely to have killed much of the soil's micro-flora, and rapid mineralization of $\mathrm{N}$ caused by rewetting in late May and June was too late to increase yields substantially; there were too few shoots and leaves to intercept light and photosynthesize. Nitrogen was taken up, however, and this increased protein in the grain.

The variation in $\mathrm{N}$ optima at site $\mathrm{F} 1$ is spatially coherent and visually matches the trends in variation of the soil $\mathrm{N}$ supply, crop $\mathrm{N}$ demand, AFR and the underlying soil series. The variation in optimum $\mathrm{N}$ was due predominantly to variation in soil $\mathrm{N}$ supply.

Clearly, there are interactions between the three components at site F1 and the importance of crop $\mathrm{N}$ demand and AFR in determining the requirement for $\mathrm{N}$ should be recognized. If a crop's demand for $\mathrm{N}$ and the AFR were constant across the field then a difference in $\mathrm{N}$ supply of $100 \mathrm{~kg} /$ ha from the soil would result in a difference in 
the requirement from fertilizer of 100/AFR kg/ha. For example, an AFR of 0.6 would be equivalent to $167 \mathrm{~kg} / \mathrm{ha}$, and here there is a difference of only c. $100 \mathrm{~kg} / \mathrm{ha}$. Surprisingly, the areas with largest supply of $\mathrm{N}$ in the soil were where the crop's demand was largest. It seems that other attributes of the soil (more water, more of the other plant nutrients, better aeration) have helped to make more $\mathrm{N}$ available to the crops and hence boost yields and demand for $\mathrm{N}$.

Measurements of soil mineral $\mathrm{N}$ made in the spring showed little variation (30-60 kg/ha) with no strong spatial coherence. It was surprising, therefore, to see the large variation in the harvested soil $\mathrm{N}$ supply. The cause for such large spatial differences in soil $\mathrm{N}$ supply is unknown; there are no clear differences in soil organic matter or soil total $\mathrm{N}$ to indicate differences in mineralization, yet in certain areas of the field the crop accessed much more nitrogen from the soil. The parts of the field where the soil $\mathrm{N}$ supply was largest were where in past years yield was also largest (Milne et al. 2012). The greater crop growth in these areas could have left more organic matter to accumulate in the soil and to mineralize and release N. It is hard to believe that such a process would supply much $\mathrm{N}$ from the soil, and so perhaps the large harvested soil $\mathrm{N}$ supply is manifest only because fertilizer was withheld. Nevertheless, it is a matter that merits further investigation.

At site $\mathrm{F} 2$, the $\mathrm{N}$ optima that were larger than zero were mostly on plots of the Worcester soil that supplied little N. Across the Worcester series the variation in $\mathrm{N}$ optima visually matched trends in variation seen in soil $\mathrm{N}$ supply. The boundary-line analysis confirmed that shortage of $\mathrm{N}$ there increased the $\mathrm{N}$ optima.

Site B1 has a Y-shaped valley where the soil is much deeper than elsewhere in the field (>90 cm compared with $30-40 \mathrm{~cm}$ elsewhere). The soil is of the Aberford series and yields more than the thinner soil elsewhere. The pattern of $\mathrm{N}$ optima for the 
site is spatially coherent, but cannot be matched to the patterns of soil $\mathrm{N}$ supply, crop $\mathrm{N}$ demand, AFR or the soil series. The boundary-line analyses helps to elucidate the factors controlling the optimum $\mathrm{N}$ somewhat. In particular, the relation between crop $\mathrm{N}$ demand and optimum $\mathrm{N}$, and the relation between soil $\mathrm{N}$ supply and optimum $\mathrm{N}$ are clearer. The points below the boundary line are of the sites where other factors are limiting optimum N. The sites on the Aberford soil lie close to the boundary, suggesting that there the supply of $\mathrm{N}$ from the soil largely determined the optimum $\mathrm{N}$. Elsewhere crop $\mathrm{N}$ demand seemed equally important. There was little evidence that fertilizer recovery played a major role in the differences in $\mathrm{N}$ requirement, yet the variation in AFR was very large $(0.3$ to $>1)$.

The three questions for which the experiments were designed are discussed below.

1. To what extent should demand for $N$ by the crop determine fertilizer recommendations?

The results show that the greater is the demand for $\mathrm{N}$ by the crop, the more fertilizer $\mathrm{N}$ should be applied. However, the effect is tempered by the interaction of the crop's demand for $\mathrm{N}$ with the $\mathrm{N}$ supplied by the soil and the fertilizer recovery. The relative importance of these factors varies from site to site and within sites, generally as a function of soil type. Knowing only one component is not enough; all components must be considered together to predict $\mathrm{N}$ fertilizer requirement with reasonable precision. Interactions between the components can vary from place to place. No evidence was found that crop $\mathrm{N}$ demand was positively related to fertilizer recovery. A new finding was the association between the crop's demand for $\mathrm{N}$ and the ability of the soil to supply it. This association should therefore be taken into account in the calculation of spatially variable requirements for $\mathrm{N}$. 


\section{How important is the soil's ability to supply nitrogen?}

The most important component determining fertilizer requirement was found to be the supply of $\mathrm{N}$ from the soil at all three sites. There was also evidence that soil $\mathrm{N}$ supply was inversely related to fertilizer recovery.

Unfortunately, current methods for predicting soil $\mathrm{N}$ supply are unsatisfactory (Kindred et al. 2012). 'Field assessment' (based on soil type and previous crop) is quick, cheap and correct on average, but it explains only c. 0.30 of field-to-field variation, and it can rarely be used to predict variation within fields. Tests for mineral $\mathrm{N}$ in the soil are more precise and precision and accuracy might be improved with assessments of mineralization; but it still does not predict more than half of field-tofield variation and it is too costly to use repeatedly within fields (Marchant et al. 2012). New ways for assessing soil $\mathrm{N}$ supply must therefore be sought by, for example canopy sensing, either via satellite, from the air or from sensors mounted on tractors. Such systems are already used by precision farmers, but not currently to estimate N supply directly. Sylvester-Bradley et al. (2009) showed that one can quantify soil $\mathrm{N}$ supply with reflectance measures by comparing NDVI of a given crop with that expected from a crop of the same age (in thermal time) that is unlimited for $\mathrm{N}$. This approach needs much development and validation, but it does offer a chance of obtaining independent estimates of soil $\mathrm{N}$ supply that are spatially variable.

\section{How variable is grain protein when the optimum $N$ is applied?}

The grain protein achieved when the crop is fertilized for a financially optimum yield is reported to be consistently around $110 \mathrm{~g} / \mathrm{kg}$ for feed varieties (Sylvester-Bradley \&

Clarke 2009). The results for fields F1 and B1 are in accord with this. Across most of field F2 the optimum $\mathrm{N}$ was zero; where it was not so the average for the optimum 
was $35.3 \mathrm{~kg} \mathrm{~N} /$ ha (see Table 6). At these fertilizer rates the average grain protein was closer to $90 \mathrm{~g} / \mathrm{kg}$.

\section{CONCLUSION}

The experiments described above and those of other investigators (e.g. Lark \& Wheeler 2003) show that there is substantial variation in the requirements for fertilizer $\mathrm{N}$ within fields and that these can be understood in terms of differences in the crops' demands for $\mathrm{N}$ (crop $\mathrm{N}$ demand) and supply of nitrogen from the soil (soil $\mathrm{N}$ supply). The positive relationship that was observed in the current work between the crop's demand for $\mathrm{N}$ and the $\mathrm{N}$ supplied by the soil $\mathrm{N}$ supply within the field is an important new consideration for farmers wishing to economize by varying the amount of fertilizer $\mathrm{N}$ they apply. The large variation in fertilizer recovery and absence of any plausible relationship with $\mathrm{N}$ optima requires further examination. It needs to be understood so that farmers can improve fertilizer recovery and the use of fertilizer to obtain larger yields without greater inputs (Sylvester-Bradley \& Withers 2013).

The current experiments support the principles behind current $\mathrm{N}$ recommendations (i.e. judging soil $\mathrm{N}$ supply and crop $\mathrm{N}$ demand), but they also leave important questions for both field-based and variable-rate $\mathrm{N}$ management. For example, should better crops be given more $\mathrm{N}$ fertilizer (because they have a greater yield potential and thus larger demand for $\mathrm{N}$ ) or less (because their thinner, less green appearance indicates less $\mathrm{N}$ is available from the soil)? In two of the three experiments, soil $\mathrm{N}$ supply was the most important in determining $\mathrm{N}$ optima, and applying more $\mathrm{N}$ to the thinner less green crop would have been most appropriate. In the third, however, it would have been better to apply more $\mathrm{N}$ to the areas of the field that were known to yield better. 
In the past it has been difficult to test the influence of individual components on the $\mathrm{N}$ optima. They have been done on different farms and fields in different years so that management and variety differences are confounded with inherent soil differences. The checkerboard experiments evidently provide an opportunity to understand how soil variation affects crops' demand for $\mathrm{N}$, the supply of $\mathrm{N}$ from the soil, fertilizer recovery and the requirement for $\mathrm{N}$ within individual fields.

The current research forms part of the Auto-N LINK project LK09134 (Reducing GHG emissions, nitrate pollution and lost productivity by fully automating $\mathrm{N}$ fertiliser management) sponsored by Defra under the Sustainable Arable LINK programme with support from AHDB-HGCA, AgLeader Technology Inc, Agrii, BASF plc, Farmade Management Systems Ltd, Foss UK Ltd, Hill Court Farm Research, Precision Decisions Ltd, SOYL, Soilessentials Ltd, Yara UK Ltd and Zeltex Inc. We thank Damian Hatley, Dennis Churchill for managing the experiments, Denise Ginsburg for handling data and Bedfordia Farms for grain protein analysis and especially John Hawthorne and Nick August for hosting the trials and applying fertilizer treatments. A.E. Milne's contribution was partly funded by the Biotechnology and Biological Sciences Research Council of the UK.

\section{REFERENCES}

AKAIKE, H. (1973). Information theory and an extension of the maximum likelihood principle. In 2nd International Symposium on Information Theory (Eds B.N. Petrov \& F. Csáki), pp. 267-281. Budapest: Akadémiai Kiadó.

Berry, P.M., Kindred, D.R., Olesen, J.E., Jorgensen, L.N. \& Paveley, N.D. (2010). Quantifying the effect of interactions between disease control, nitrogen 
supply and land use change on the greenhouse gas emissions associated with wheat production. Plant Pathology 59, 753-763.

BISHOP, T.F.A. \& LARK, R.M. (2006). The geostatistical analysis of experiments at the landscape-scale. Geoderma 133, 87-106.

Bloom, T.M., Sylvester-Bradley, R., Vaidyanathan, L.V. \& Murray, A.W.A. (1988). Apparent recovery of fertiliser nitrogen by winter wheat. In Nitrogen Efficiency in Agricultural Soils (Eds D. S. Jenkinson \& K. A. Smith), pp. 27-37. Barking, UK: Elsevier Applied Science.

Boyd, D.A., Yuen, L.T.K. \& NeEdHAM, P. (1976). Nitrogen requirement of cereals. Part I: Response curves. Journal of Agricultural Science, Cambridge 87, 149162.

DEFRA (2010). The Fertiliser Manual (RB209). Fertiliser Recommendations for Agricultural and Horticultural Crops. Ed. 8 London: TSO.

GRINDLAY, D.J.C. (1997). Towards an explanation of crop nitrogen demand based on the optimization of leaf nitrogen per unit leaf area. Journal of Agricultural Science, Cambridge 128, 377-396.

Heege, H.J., Reusch, S. \& Thiessen, E. (2008). Prospects and results for optical systems for site-specific on-the-go control of nitrogen-top-dressing in Germany. Precision Agriculture 9, 115-131.

HGCA (2013). HGCA Recommended Lists 2013/14 for Cereals and Oilseeds. Stoneleigh, UK: Home Grown Cereals Authority.

Jarvis, M.G., Allen, R.H., Fordham, S.J., Hazelden, J., Moffat, A.J. \& Sturdy, R.G. (1984). Soils and their Use in South East England. Soil Survey of England and Wales Bulletin No 15. Harpenden, UK: Lawes Agricultural Trust (Soil Survey of England and Wales). 
Kindred, D.R., Knight, S., Berry, P., Sylvester-Bradley, R., Hatley, D., Morris, N., HoAd, S. \& White, C. (2012) Establishing Best Practice for Estimation of Soil N Supply. HGCA Project Report No 490. London: HGCA.

Knight, S., Macdonald, A., Glendining, M., Whitmore, A., Dailey, G., Goulding, K., Sinclair, A. \& Rees, B. (2008). Better Estimation of Soil Nitrogen Use Efficiency by Cereals and Oilseed Rape. HGCA Research Review 68. London: HGCA.

LARK, R.M. \& WHEELER, H.C. (2003). A method to investigate within-field variation of the response to combinable crops to an input. Agronomy Journal 95, 10931104.

Lemaire, G., Van Oosterom, E., Sheehy, J., Jeuffroy, M.H., Massignam, A. \& Rossato, L. (2007). Is crop $\mathrm{N}$ demand more closely related to dry matter accumulation or leaf area expansion during vegetative growth? Field Crops Research 100, 91-106.

Marchant, B.P., Dailey, A.G. \& Lark, R.M. (2012). Cost Effective Sampling Strategies for Soil Management. HGCA Project Report 485. Harpenden, UK: HGCA.

Milne, A.E., Ferguson, R.B. \& LARK, R.M. (2006). Estimating a boundary line model for a biological response by maximum likelihood. Annals of Applied Biology 149, 223-234.

Milne, A.E., Webster, R., Ginsberg, D. \& Kindred, D. (2012). Spatial multivariate classification of an arable field into compact management zones based on past crop yields. Computers \& Electronics in Agriculture 80, 17-30. 
Pask, A.J.D., Sylvester-Bradley, R., Jamieson, P.D. \& Foulkes, M.J. (2012). Quantifying how winter wheat crops accumulate and use nitrogen reserves during growth. Field Crops Research 126, 104-118.

Payne, R.W., Harding, S.A., Murray, D.A., Soutar, D.M., Baird, D.B., Glaser, A.I., Welham, S.J., Gilmour, A.R., Thompson, R. \& Webster, R. (2011). The Guide to GenStat, Release 14 - Part 2 Statistics. Hemel Hempstead, UK: VSN International.

Pringle, M.J., Mcbratney, A.B. \& Cook, S.E. (2004). Field-scale experiments for site specific crop management. Part II: a geostatistical analysis. Precision Agriculture 5, 625-645.

RagG, J.M., Beard, G.R., George, H., Heaven, F.W., Hollis, J.M., Jones, R.J.A., Palmer, R.C., Reeve, M.J., Robson, J.D. \& Whitfield, W.A.D. (1984). Soils and their Use in Midland and Western England. Soil Survey of England and Wales Bulletin No 12. Harpenden, UK: Lawes Agricultural Trust (Soil Survey of England and Wales).

Sutton, M.A., Howard, C.M., Erisman, J.W., Billen, G., Bleeker, A., Grennfelt, P., Van Grinsven, H. \& Grizzetti, B. (2011). The European Nitrogen Assessment. Cambridge, UK: Cambridge University Press.

SylVESTER-BRADley, R. (2009). Nitrogen for Winter Wheat - Management Guidelines. Stoneleigh, UK: HGCA.

Sylvester-Bradley, R. \& Clarke, S. (2009). Using Grain N\% as a Signature for Good N Use. HGCA Project Report No 458. London: HGCA.

Sylvester-Bradley, R., Wiltshire, J.J.J., Kindred, D.R., Hatley, D.L.J. \&Clarke, S. (2009). Detecting Soil Nitrogen Supplies by Canopy Sensing. Proof of Concept - Phase 2. HGCA Project Report 460. London: HGCA. 
SYlVESTER-BRADley, R. \& KindRED, D.R. (2009). Analysing nitrogen responses of cereals to prioritize routes to the improvement of nitrogen use efficiency. Journal of Experimental Botany 60, 1939-1951.

Sylvester-Bradley, R., Kindred, D.R., Blake, J., Dyer, C.J. \& Sinclair, A.H. (2008). Optimising Fertiliser Nitrogen for Modern Wheat and Barley Crops. HGCA Final Report Project No 438. London: HGCA.

Sylvester-Bradley, R., Kindred, D.R., Wynn, S.C., Thorman, R.E. \& SMith, K.E. (2012). Efficiencies of nitrogen fertilizers for winter cereal production, with implications for greenhouse gas intensities of grain. Journal of Agricultural Science, Cambridge (2012), DOI: 10.1017/S0021859612000810.

Sylvester-Bradley, R. \& Withers, P.J.A. (2013). Innovating in Crop Nutrition to Support Potential Crop Yields. Proceedings of the International Fertiliser Society 715. Leek, UK: International Fertiliser Society.

WEBB, R.A. (1972). Use of the boundary line in analysis of biological data. Journal of Horticultural Science 47, 309-319. 
Table 1. Soil types at Flawborough and Burford and their characteristics. See Ragg et al. (1984) and Jarvis et al. (1984) for more details

\begin{tabular}{ll}
\hline Soil series & Main characteristics and substrates \\
and intergrades & \\
\hline Evesham & Strongly structured calcareous swelling clay over Lower Lias \\
& shale \\
Worcester & Reddish brown clay over Permo-Triassic mudstone and shale \\
Evesham-Worcester & Intermediate between Evesham and Worcester series \\
Fladbury & Low-lying alluvial clay, seasonally waterlogged \\
Worcester- Fladbury & Intermediate between Worcester and Fladbury series \\
Elmton & Brown clay loam or sandy clay loam containing 10-50\% \\
& stone to $c .50$ cm over limestone brash \\
Aberford & Brown slightly to moderately stony clay loam or sandy clay \\
& loam to $c .80 \mathrm{~cm}$ over limestone brash \\
\hline
\end{tabular}


Table 2. Average temperatures and total rainfall at Flawborough during seasons 2009/10 and 2010/11 and at Burford during season 2010/11

\begin{tabular}{|c|c|c|c|c|c|c|}
\hline \multirow{4}{*}{ Month } & \multicolumn{2}{|c|}{ Flawborough } & \multicolumn{2}{|c|}{ Flawborough } & \multicolumn{2}{|c|}{ Burford } \\
\hline & & $9 / 10$ & & $0 / 11$ & & $10 / 11$ \\
\hline & Total & Average & Total & Average & Total & Average \\
\hline & rainfall & temperature & rainfall & temperature & rainfall & temperature \\
\hline Sept & 16.8 & 14 & 49.5 & 12.8 & 41.4 & 13.7 \\
\hline Oct & 59.7 & 11.4 & 59.7 & 9.1 & 54.4 & 10.2 \\
\hline Nov & 87.6 & 8.4 & 44.7 & 4.5 & 55.3 & 5 \\
\hline Dec & 56.9 & 3.1 & 19.6 & -0.9 & 22.4 & -0.8 \\
\hline Jan & 41.4 & 1.6 & 32.8 & 3.2 & 60.4 & 3.6 \\
\hline Feb & 50.8 & 2.4 & 51.8 & 6.1 & 50.5 & 6.3 \\
\hline Mar & 40.9 & 5.3 & 9.1 & 6.3 & 10.0 & 7.0 \\
\hline April & 29.7 & 8.3 & 7.4 & 10.9 & 4.6 & 12.3 \\
\hline May & 28.2 & 10.2 & 47.8 & 11.9 & 41.2 & 12.4 \\
\hline June & 40.1 & 14.6 & 35.8 & 14.1 & 49.1 & 14.1 \\
\hline July & 36.8 & 16.7 & 54.9 & 15.1 & 44.7 & 15.8 \\
\hline Aug & 110.2 & 14.6 & 56.6 & 15.5 & 52.9 & 15.9 \\
\hline
\end{tabular}


Table 3. Summary statistics of the yield data at four rates of fertilizer $N(\mathrm{~kg} / \mathrm{ha})$ in fields F1, F2 and B1

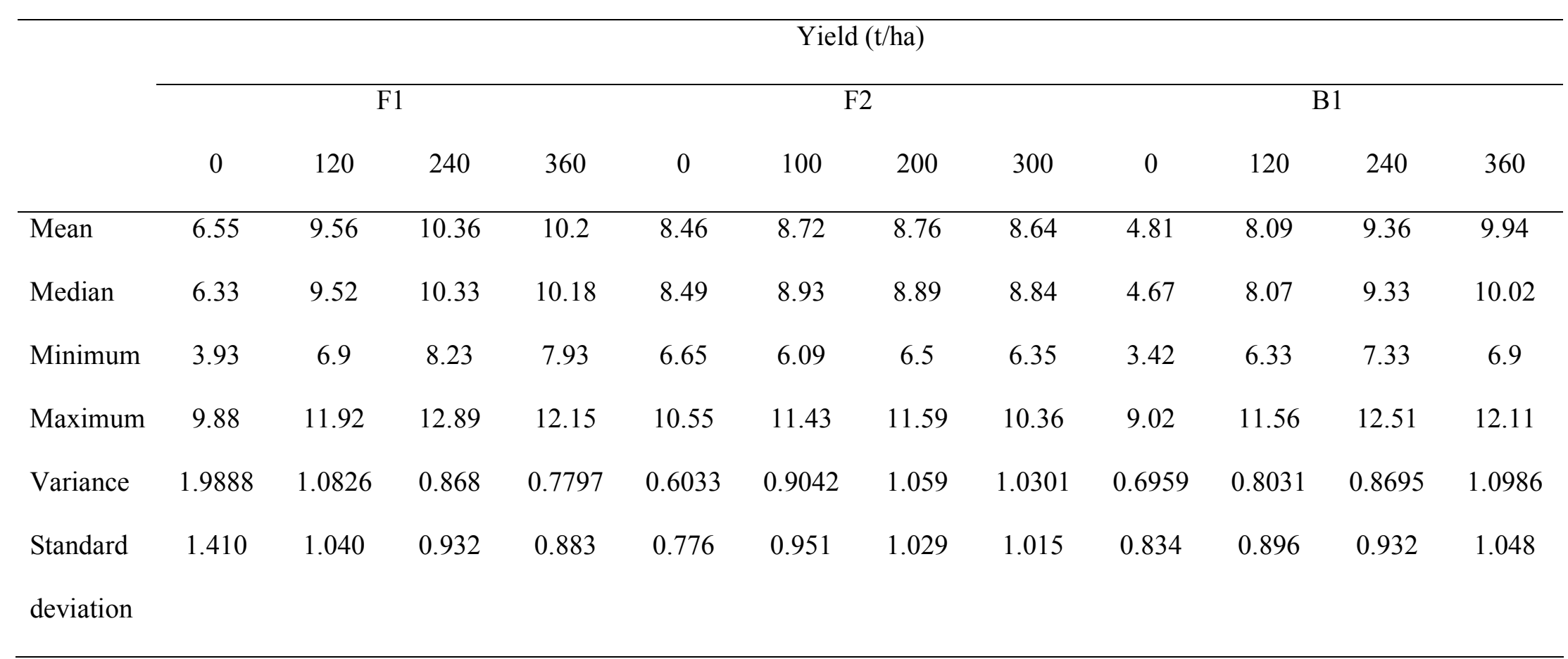


Table 4. Summary statistics of the grain protein data at four rates for fertilizer $N(\mathrm{~kg} / \mathrm{ha})$ in fields F1, F2 and B1

\begin{tabular}{|c|c|c|c|c|c|c|c|c|c|c|c|c|}
\hline & \multicolumn{12}{|c|}{ Protein $(\mathrm{g} / \mathrm{kg}$ dry matter) } \\
\hline & \multicolumn{4}{|c|}{ F1 } & \multicolumn{4}{|c|}{ F2 } & \multicolumn{4}{|c|}{ B1 } \\
\hline & 0 & 120 & 240 & 360 & 0 & 100 & 200 & 300 & 0 & 120 & 240 & 360 \\
\hline Mean & 91.1 & 95.2 & 131.2 & 133.8 & 88.4 & 98.4 & 109 & 112.5 & 92.3 & 10.3 & 114.9 & 126.6 \\
\hline Median & 91 & 94 & 131 & 133 & 88.5 & 97.9 & 108.4 & 112.4 & 91 & 102.6 & 114.1 & 126 \\
\hline Minimum & 76 & 83 & 118 & 126 & 65.8 & 81.9 & 92.7 & 102 & 81.3 & 92.8 & 96.7 & 114.9 \\
\hline Maximum & 122 & 126 & 138 & 147 & 115.9 & 114.4 & 127.4 & 131.9 & 125.5 & 122.4 & 134.2 & 151.1 \\
\hline Variance & 52.88 & 50.94 & 12.45 & 15.97 & 84.63 & 56.98 & 30.83 & 35.31 & 66.79 & 40.41 & 56.72 & 70.39 \\
\hline Standard & 7.272 & 7.137 & 3.528 & 3.996 & 9.199 & 7.549 & 5.552 & 5.942 & 8.173 & 6.357 & 7.531 & 8.390 \\
\hline deviation & & & & & & & & & & & & \\
\hline
\end{tabular}


Table 5. Summary statistics of the crop $N$ uptake at four rates for fertilizer $N(\mathrm{~kg} / \mathrm{ha})$ in fields $F 1, F 2$ and B1

\begin{tabular}{|c|c|c|c|c|c|c|c|c|c|c|c|c|}
\hline & \multicolumn{12}{|c|}{ Crop N uptake (kg/ha) } \\
\hline & \multicolumn{4}{|c|}{ F1 } & \multicolumn{4}{|c|}{ F2 } & \multicolumn{4}{|c|}{ B1 } \\
\hline & 0 & 120 & 240 & 360 & 0 & 100 & 200 & 300 & 0 & 120 & 240 & 360 \\
\hline Mean & 108.3 & 160.6 & 239.5 & 248.7 & 130.8 & 149.7 & 167.2 & 170 & 78.4 & 154.3 & 199.2 & 232.9 \\
\hline Median & 107 & 154.3 & 239.3 & 249.6 & 127 & 148.7 & 167 & 169.7 & 77.8 & 148.7 & 195.2 & 234.9 \\
\hline Minimum & 59.76 & 115.2 & 192.5 & 192.9 & 94.72 & 99.73 & 105.7 & 136.2 & 56.7 & 118 & 166.7 & 170.7 \\
\hline Maximum & 177.7 & 230.3 & 285.9 & 292 & 175.3 & 183.8 & 212.2 & 204.8 & 141.3 & 215.9 & 259.8 & 284.6 \\
\hline Variance & 769.5 & 624.3 & 444.9 & 425.7 & 225.9 & 170.7 & 296.9 & 257 & 175.6 & 575.2 & 535.3 & 571.9 \\
\hline Standard & 27.74 & 24.99 & 21.09 & 20.63 & 15.03 & 13.07 & 17.23 & 16.03 & 13.25 & 23.98 & 23.14 & 23.92 \\
\hline deviation & & & & & & & & & & & & \\
\hline
\end{tabular}


Table 6. Summary statistics of the estimated optimum $N$ (in $\mathrm{kg} / \mathrm{ha}$ ) for fields F1, F2 and B1. Plots where the optimum $N$ was zero or where over-fertilization meant that the optima could not be reliably calculated have been excluded

\begin{tabular}{lccc}
\hline & F1 & F2 & B1 \\
\hline Number of values & 527 & 90 & 373 \\
Number of missing values & 1 & 342 & 3 \\
Mean & 147.3 & 35.3 & 240.2 \\
Median & 148.5 & 34.5 & 241.0 \\
Minimum & 75.6 & 1.47 & 162.3 \\
Maximum & 183.7 & 84.4 & 282.7 \\
Variance & 357.29 & 427.95 & 272.26 \\
Standard deviation & 18.90 & 20.69 & 16.50 \\
Average standard error & 12.25 & 48.46 & 18.13 \\
\hline
\end{tabular}


Table 7. Parameters for predictors of optimum $N$, obtained from boundary line analysis or by simple linear regression. The error associated with the boundary line (c) and the $\mathrm{R}^{2}$ values for the regression lines are also reported

\begin{tabular}{|c|c|c|c|c|c|c|}
\hline Field & $\begin{array}{l}\text { Explanatory } \\
\text { variable }\end{array}$ & Soil series & $a$ & $b$ & $\hat{\sigma}$ & $R^{2}$ \\
\hline F1 & $\begin{array}{l}\text { Crop N uptake with } \\
360 \mathrm{~kg} \mathrm{~N} / \text { ha applied }\end{array}$ & $\begin{array}{l}\text { All except } \\
\text { Fladbury }\end{array}$ & 0.63 & 8.91 & 4.11 & \\
\hline F1 & $\begin{array}{l}\text { Crop N uptake with } \\
360 \mathrm{~kg} \mathrm{~N} / \mathrm{ha} \text { applied }\end{array}$ & Fladbury & 0.44 & 65.37 & 3.54 & \\
\hline B1 & $\begin{array}{l}\text { Crop N uptake with } \\
360 \mathrm{~kg} \mathrm{~N} / \text { ha applied }\end{array}$ & All types & 0.37 & 156.3 & & 0.41 \\
\hline F1 & $\begin{array}{l}\text { Harvested soil N } \\
\text { supply }\end{array}$ & $\begin{array}{l}\text { All except } \\
\text { Fladbury }\end{array}$ & -0.61 & 214.63 & 12.59 & \\
\hline F1 & $\begin{array}{l}\text { Harvested soil N } \\
\text { supply }\end{array}$ & Fladbury & -0.77 & 221.71 & 6.54 & \\
\hline $\mathrm{F} 2$ & $\begin{array}{l}\text { Harvested soil N } \\
\text { supply }\end{array}$ & All types & -1.29 & 212.52 & 13.48 & \\
\hline B1 & $\begin{array}{l}\text { Harvested soil N } \\
\text { supply }\end{array}$ & All types & -1.11 & 342.69 & 8.64 & \\
\hline $\mathrm{F} 1$ & $\mathrm{~N}$ uptake & $\begin{array}{l}\text { All except } \\
\text { Fladbury }\end{array}$ & 184.63 & 52.05 & 12.18 & \\
\hline F1 & $\mathrm{N}$ uptake & Fladbury & 211.81 & 24.64 & 10.88 & \\
\hline
\end{tabular}


Fig. 1. a) The design of the chequer board experiment in field F1 at Flawborough. The plots were fertilized with either $0,120,240$ or $360 \mathrm{~kg} \mathrm{~N} / \mathrm{ha} ; b)$ An aerial photograph of Flawborough field F1 during the chequerboard experiment.

Fig. 2. Field 1. a) the soil series, from left to right, Fladbury, Worcester-Fladbury, Worcester, Worcester-Evesham and Evesham; $b$ ) optimum $\mathrm{N} ; c$ ) the standard error of optimum $\mathrm{N} ; d$ ) estimates of crop $\mathrm{N}$ demand; $e$ ) estimates of soil $\mathrm{N}$ supply; and $f$ ) model based estimates of AFR.

Fig. 3. Field F2. $a$ ) the soil series, from left to right, Fladbury, Worcester; $b$ ) optimum $\mathrm{N} ; c$ ) the standard error of optimum $\mathrm{N} ; d$ ) estimates of crop $\mathrm{N}$ demand; $e$ ) estimates of soil N supply; and $f$ ) model based estimates of AFR.

Fig. 4. Field B1. a) the soil series are Elmton and Aberford (Y-shaped valley); b) optimum $\mathrm{N} ; c$ ) the standard error of optimum $\mathrm{N} ; d$ ) estimates of crop $\mathrm{N}$ demand; $e$ ) estimates of soil $\mathrm{N}$ supply; and f) model based estimates of AFR.

Fig. 5. The optimum $\mathrm{N}$ plotted against crop $\mathrm{N}$ uptake with a) $360 \mathrm{~kg} \mathrm{~N} /$ ha in field F1, b) $300 \mathrm{~kg} \mathrm{~N} / \mathrm{ha}$ in field $\mathrm{F} 2$, and c) $360 \mathrm{~kg} \mathrm{~N} / \mathrm{ha}$ in field B1, with the fitted models. The model parameters are reported in Table 7.

Fig. 6. The optimum $\mathrm{N}$ (in $\mathrm{kg} \mathrm{N} / \mathrm{ha}$ ) plotted against harvested soil $\mathrm{N}$ supply (in $\mathrm{kg}$ $\mathrm{N} /$ ha) for fields $a$ ) F1, b) F2 and c) B1, with the fitted models. The model parameters are reported in Table 7. 
Fig. 7. The optimum $\mathrm{N}(\mathrm{kg} \mathrm{N} / \mathrm{ha}$ ) plotted against estimated AFR for field $a$ ) F1 with the fitted model, $b$ ) F2, and $c$ ) B1. The model parameters are reported in Table 7. 
a)

\begin{tabular}{|c|c|c|c|c|c|c|c|c|}
\hline & 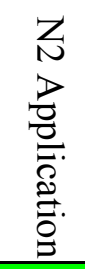 & 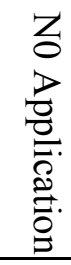 & 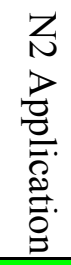 & 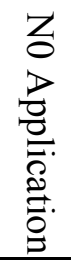 & 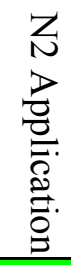 & 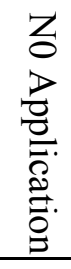 & 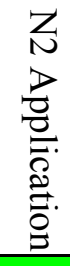 & 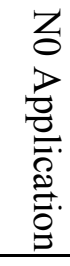 \\
\hline \multicolumn{9}{|l|}{ N0 Application } \\
\hline & N2 & N0 & $\mathrm{N} 2$ & No & N2 & N0 & $\mathrm{N} 2$ & N0 \\
\hline \multicolumn{9}{|l|}{ N1 Application } \\
\hline & N3 & N1 & N3 & N1 & N3 & N1 & N3 & N1 \\
\hline \multicolumn{9}{|l|}{ N0 Application } \\
\hline & N2 & N0 & $\mathrm{N} 2$ & No & N2 & N0 & N2 & N0 \\
\hline \multicolumn{9}{|l|}{ N1 Application } \\
\hline & N3 & N1 & N3 & N1 & N3 & N1 & N3 & N1 \\
\hline \multicolumn{9}{|l|}{ N0 Application } \\
\hline & N2 & No & $\mathrm{N} 2$ & N0 & $\mathrm{N} 2$ & No & $\mathrm{N} 2$ & N0 \\
\hline \multicolumn{9}{|l|}{ N1 Application } \\
\hline & N3 & N1 & N3 & N1 & N3 & N1 & N3 & N1 \\
\hline \multicolumn{9}{|l|}{ N0 Application } \\
\hline & N2 & No & $\mathrm{N} 2$ & No & $\mathrm{N} 2$ & No & N2 & N0 \\
\hline \multicolumn{9}{|l|}{ N1 Application } \\
\hline & N3 & N1 & N3 & N1 & N3 & N1 & N3 & N1 \\
\hline
\end{tabular}


b)

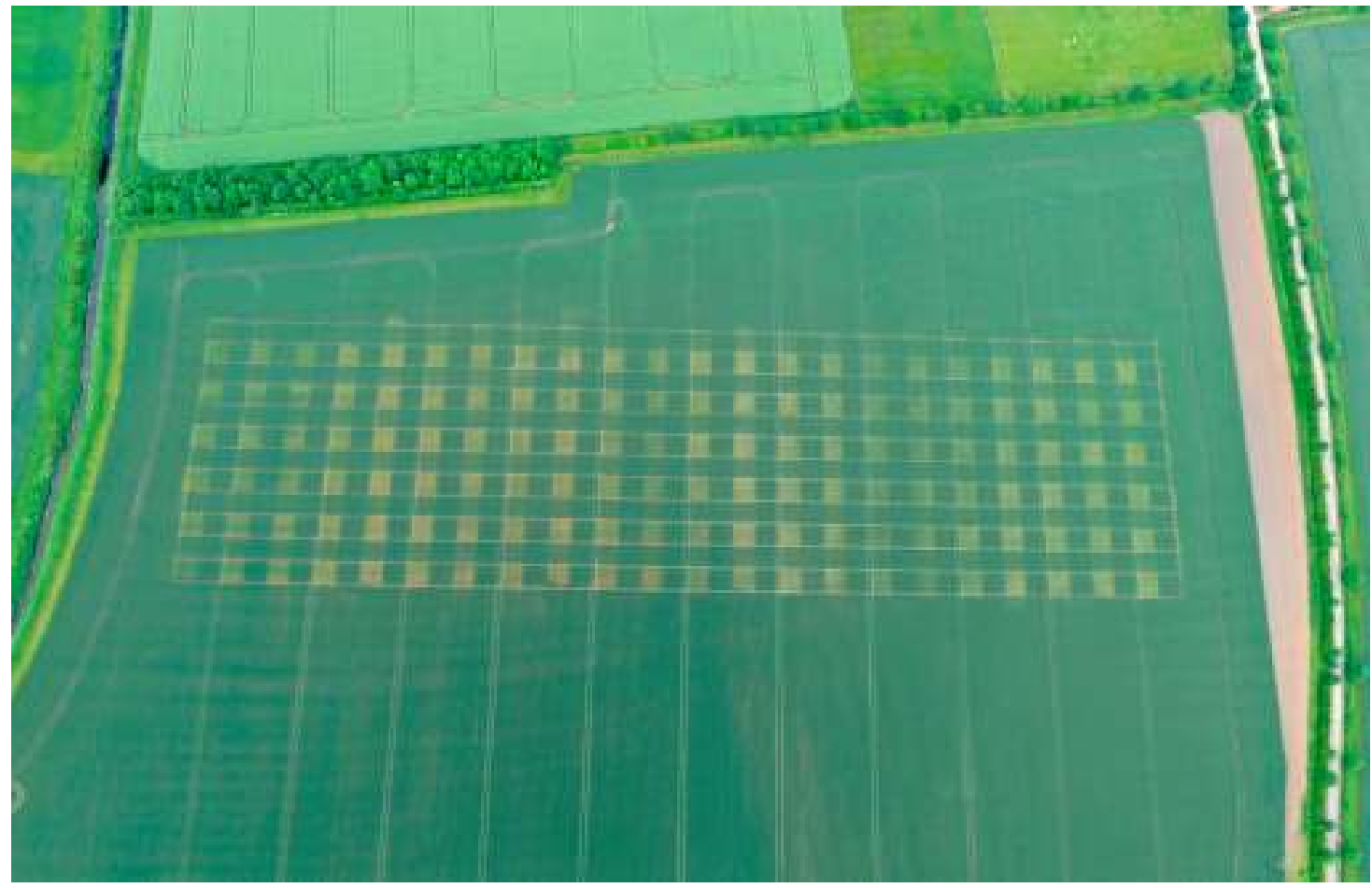

Fig. 1. 
a)

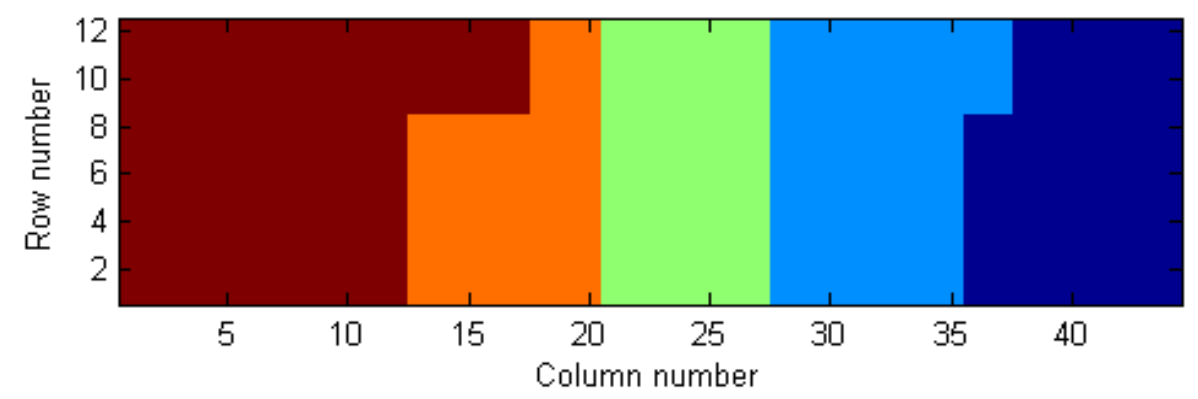

b)

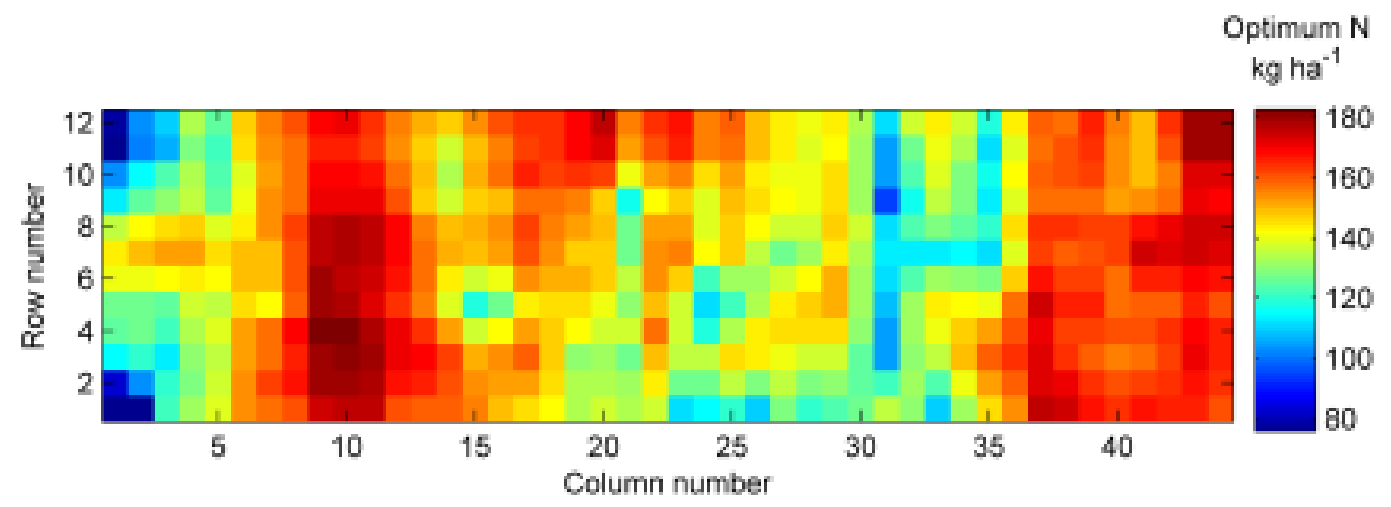

c)

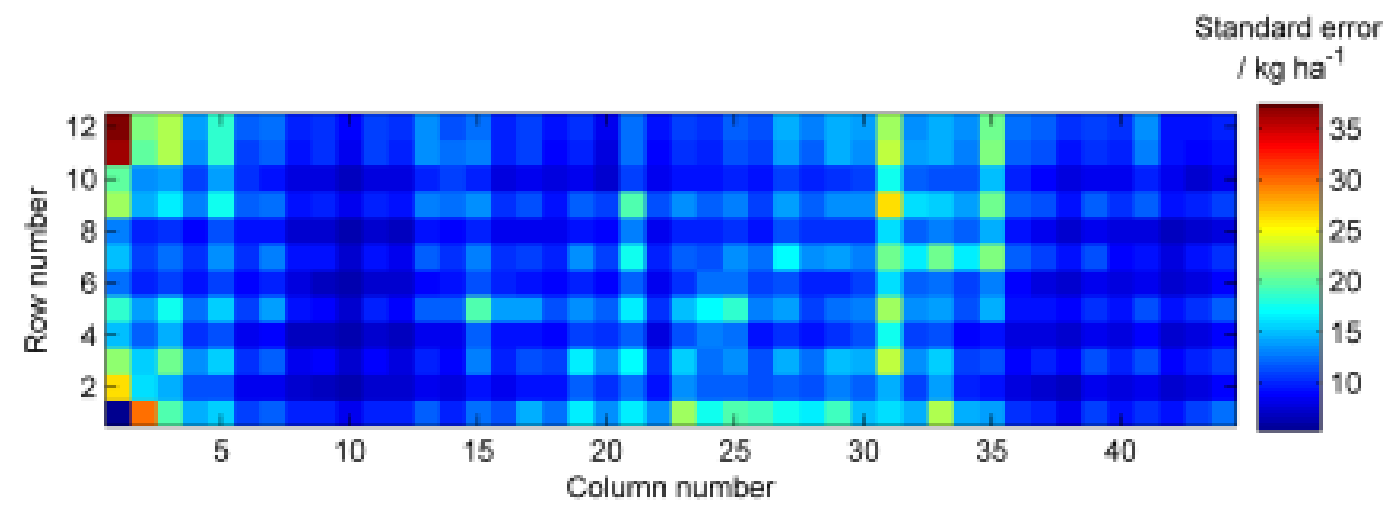




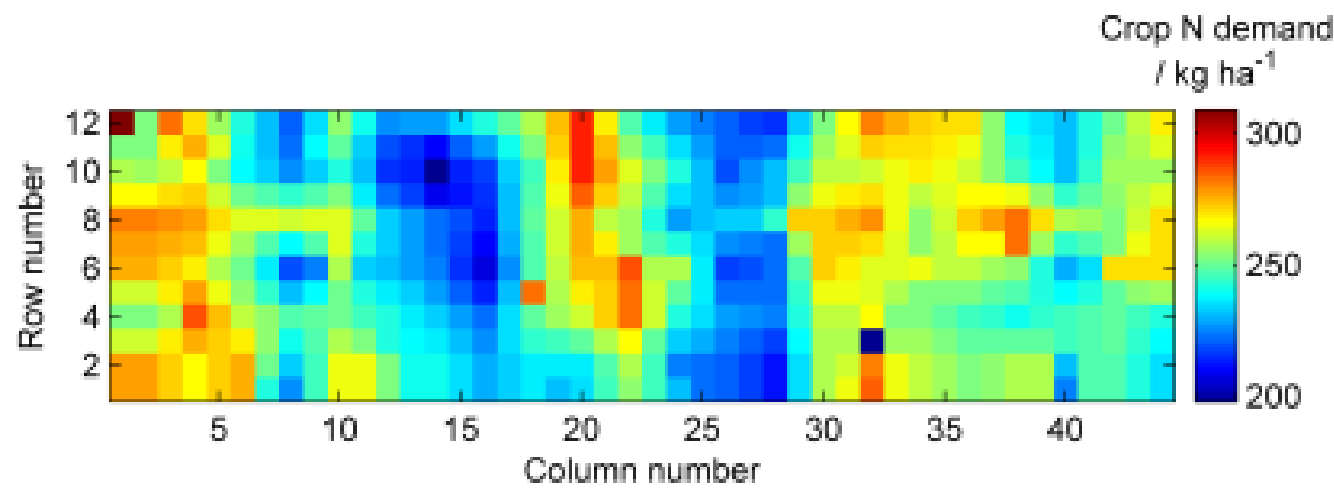

e)

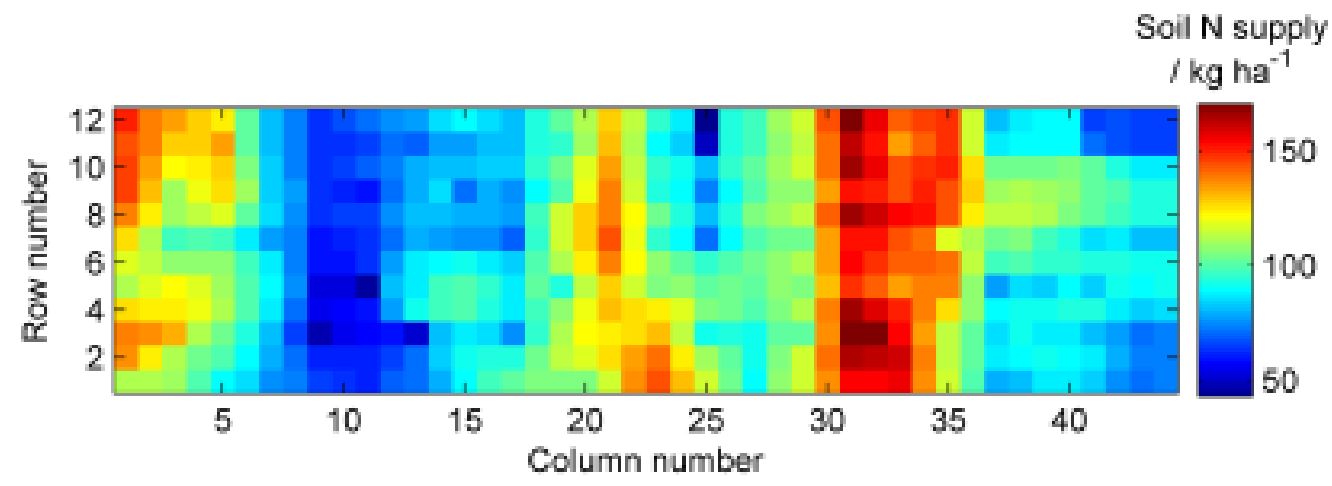

f)

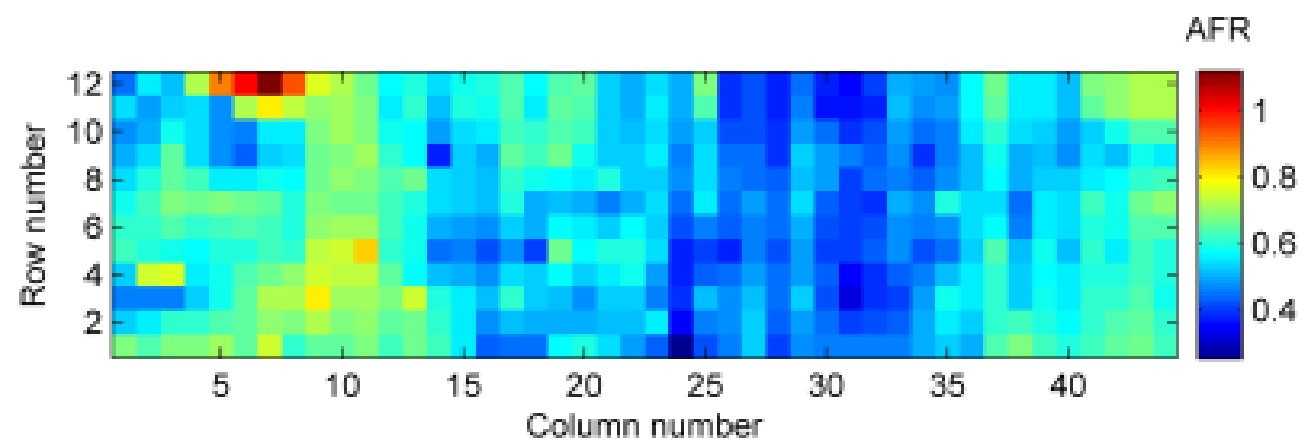

Fig. 2. 
a)

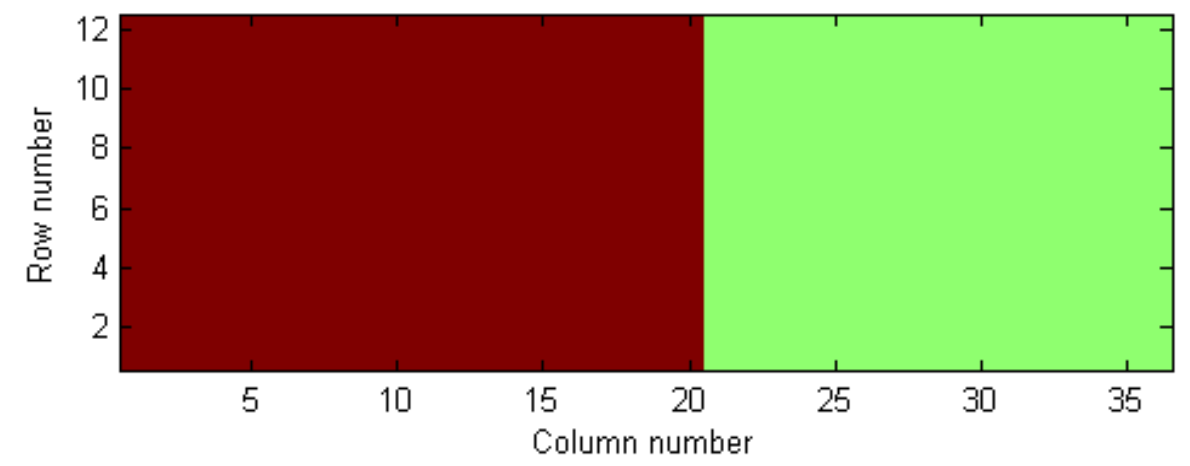

b)

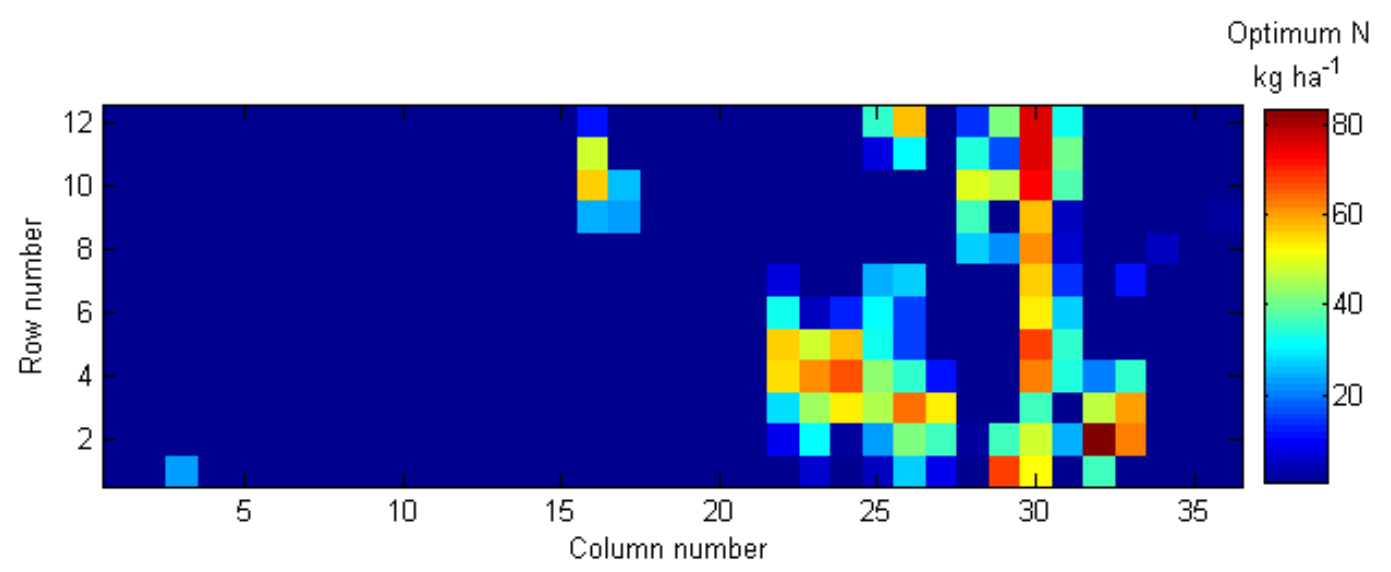

c)

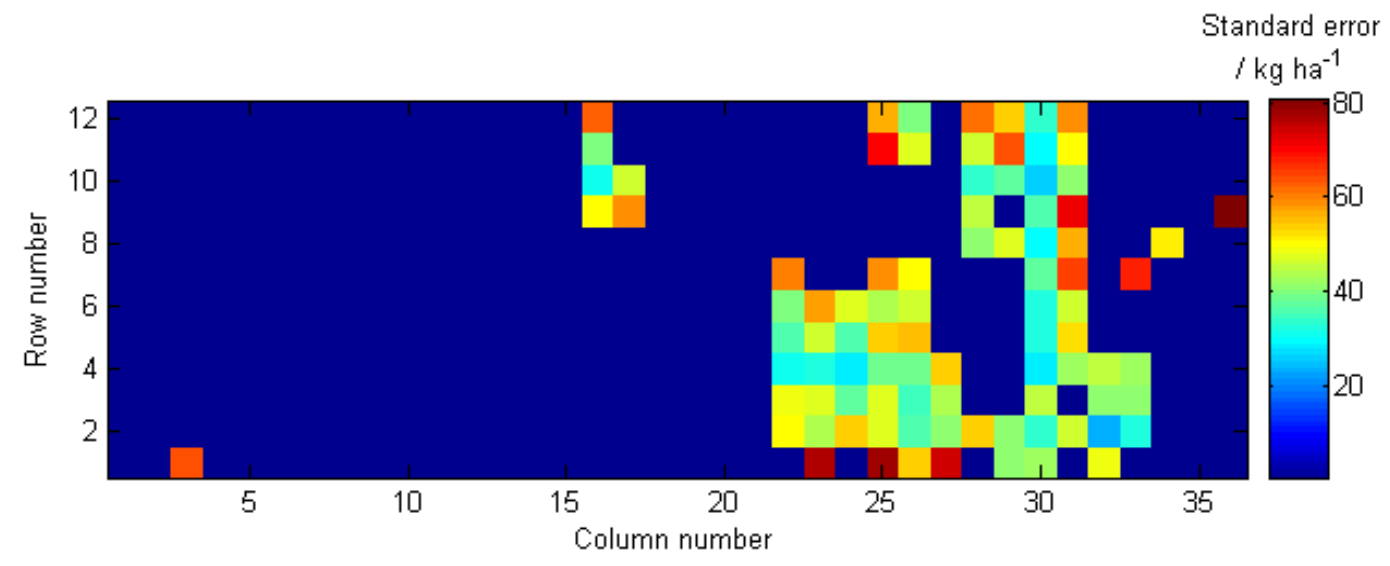




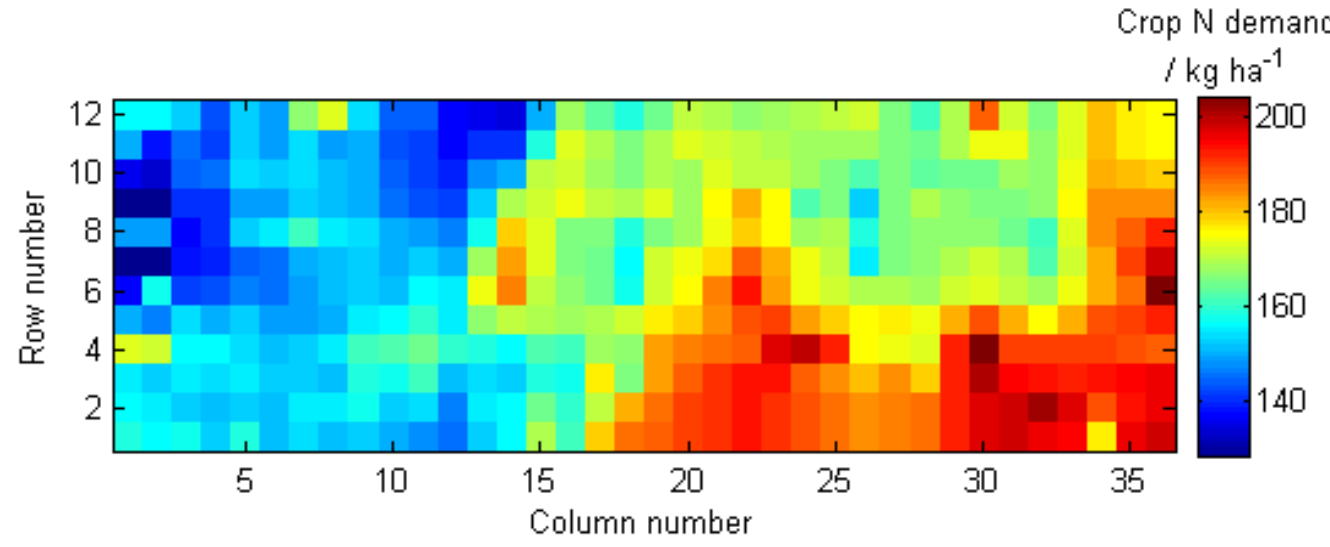

e)

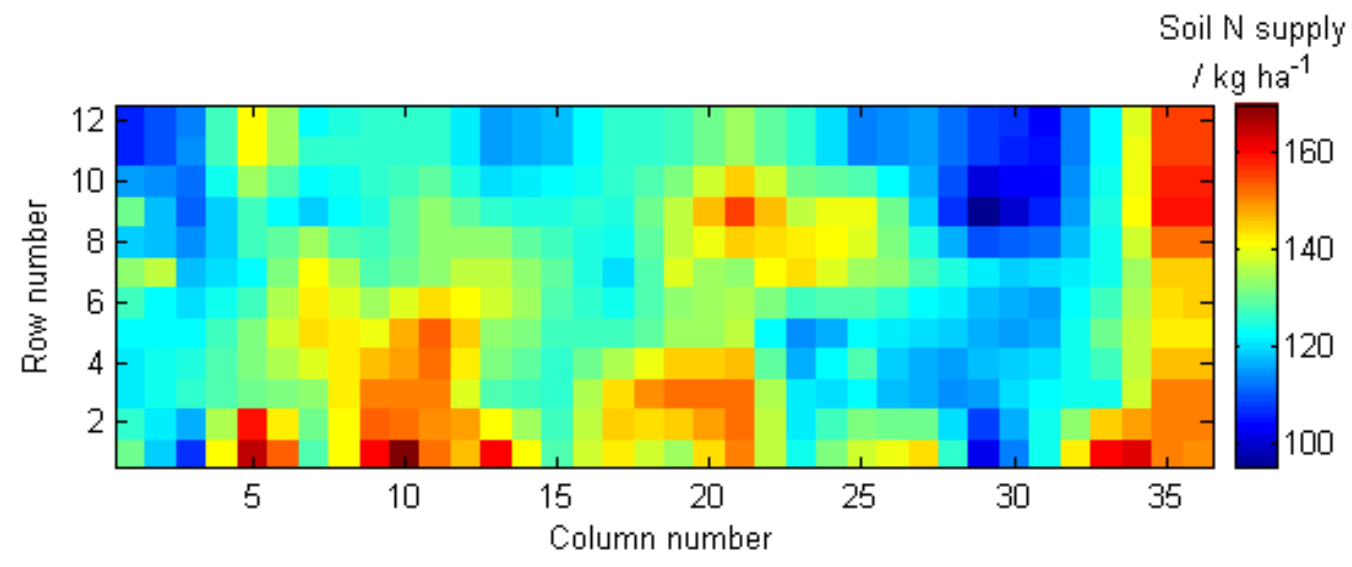

f)

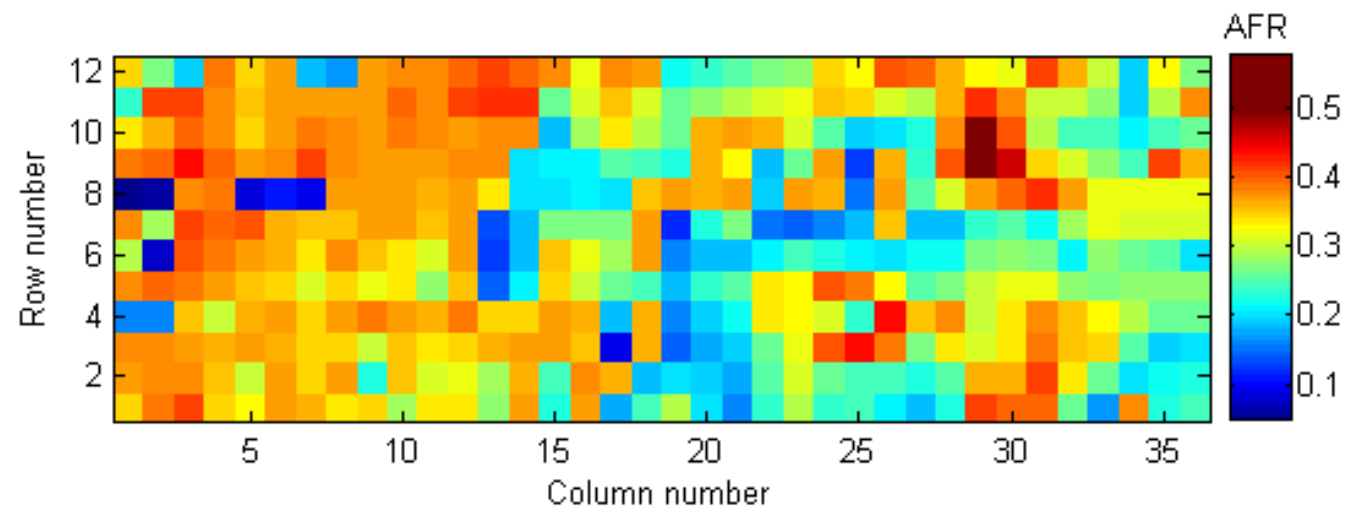

Fig. 4. 
a)

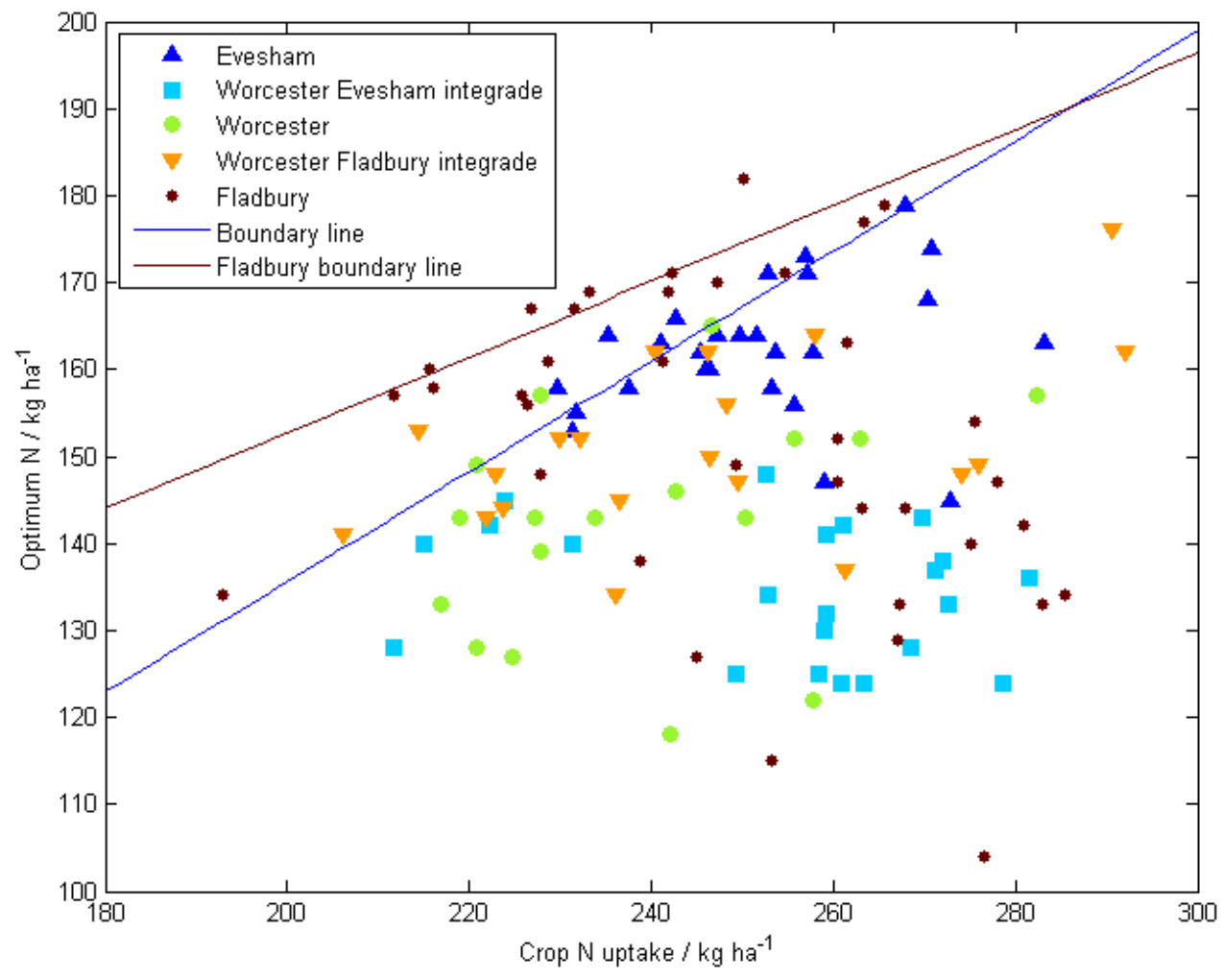

b) 


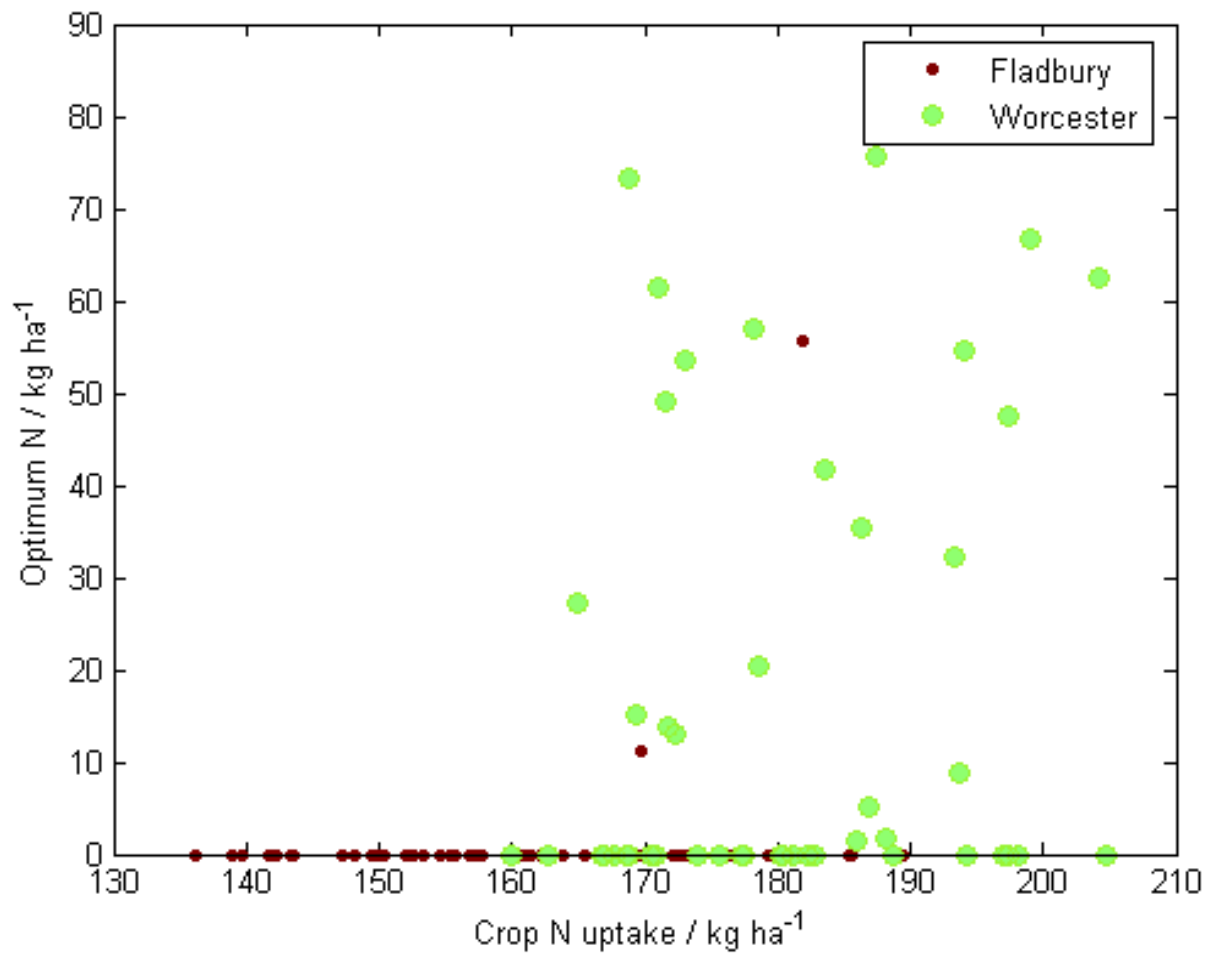

c)

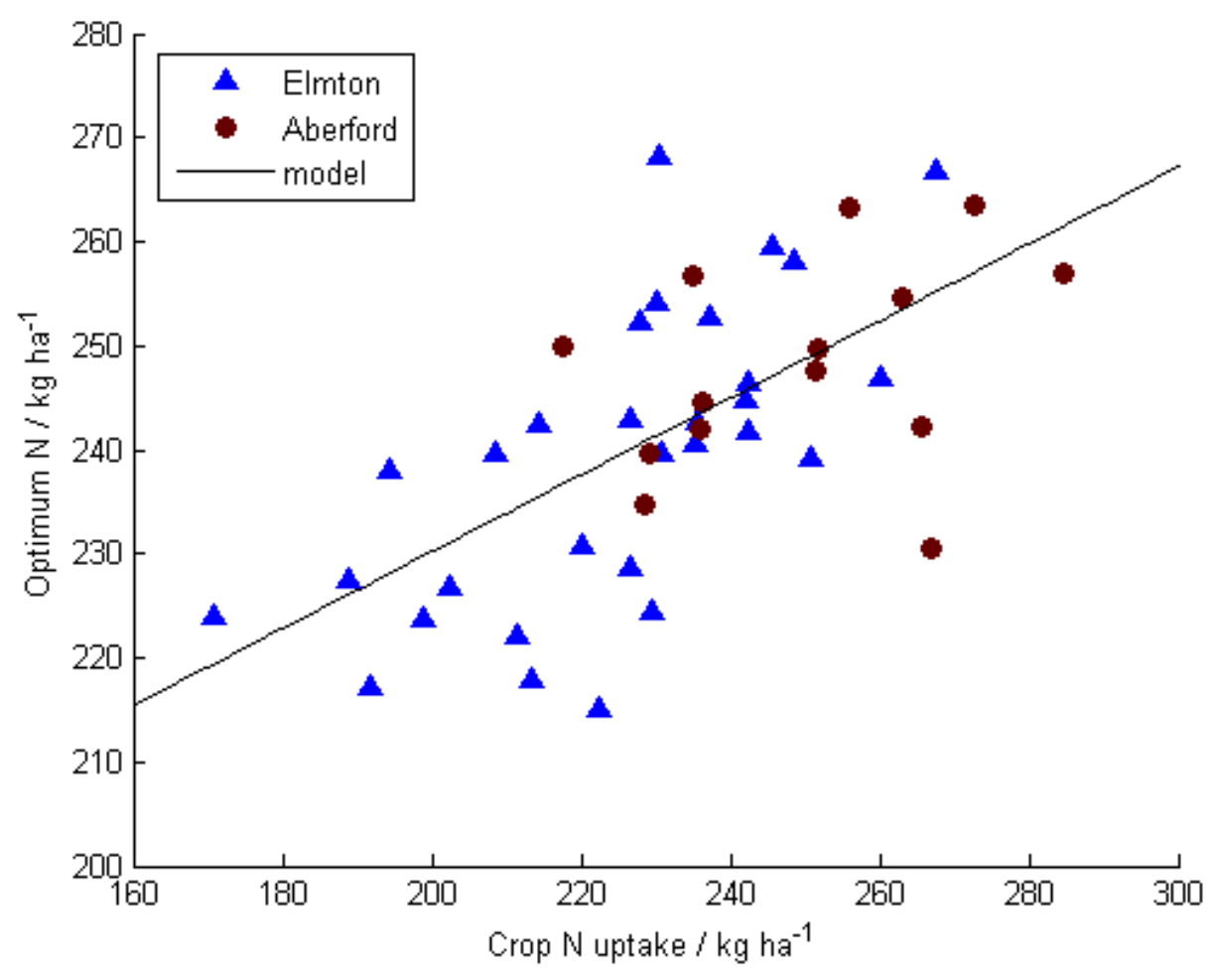

Fig. 5. 
a)

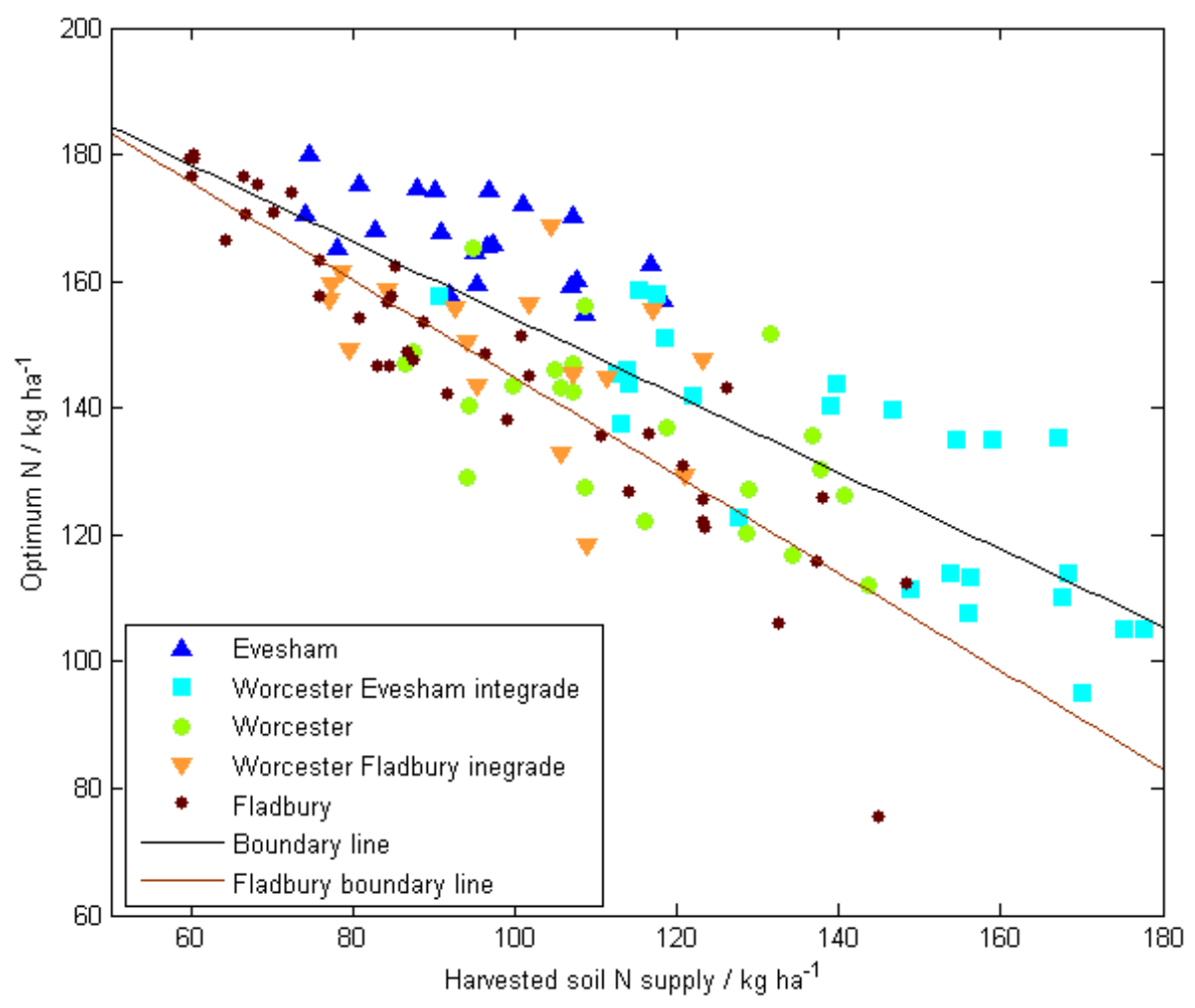

b) 


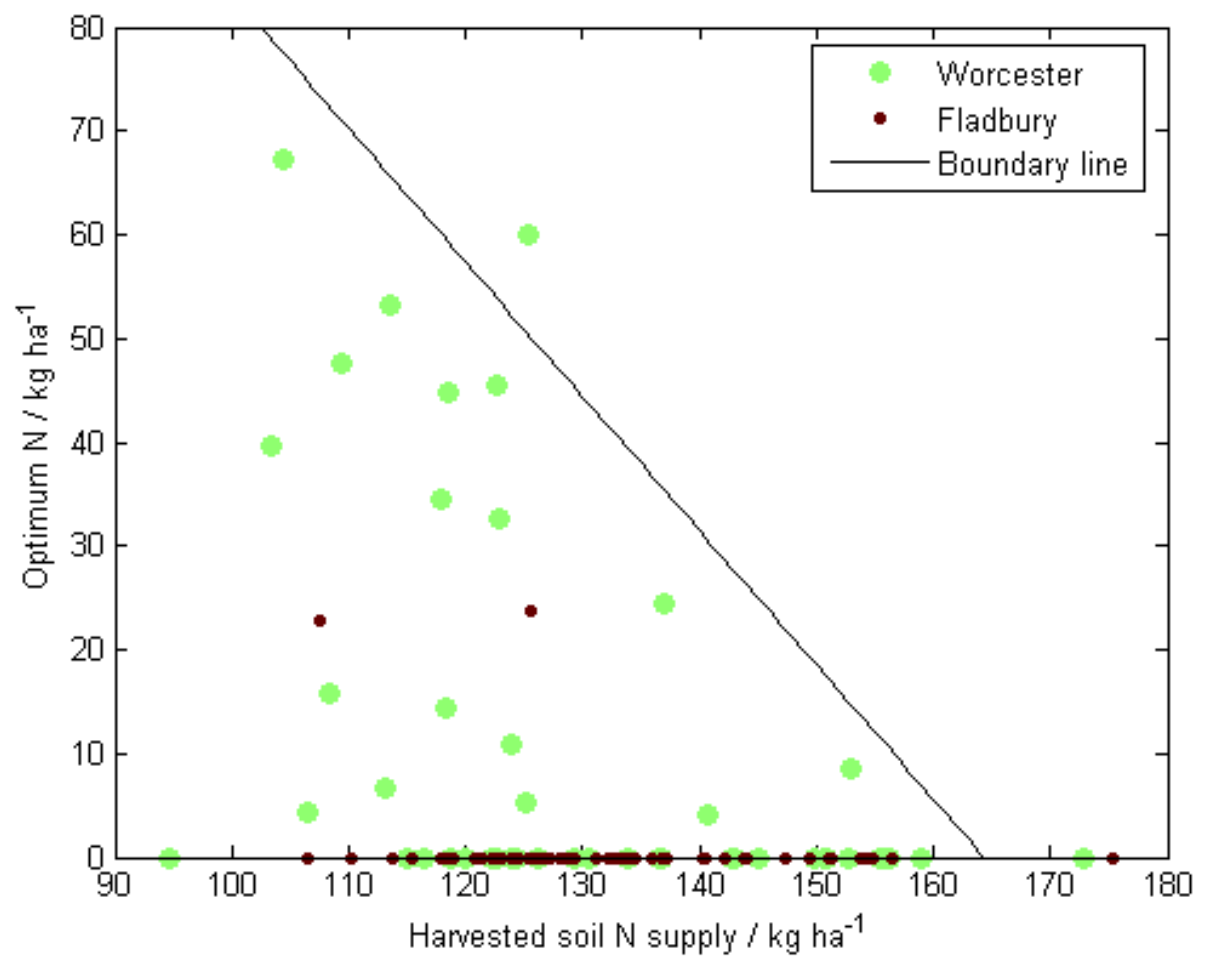

c)

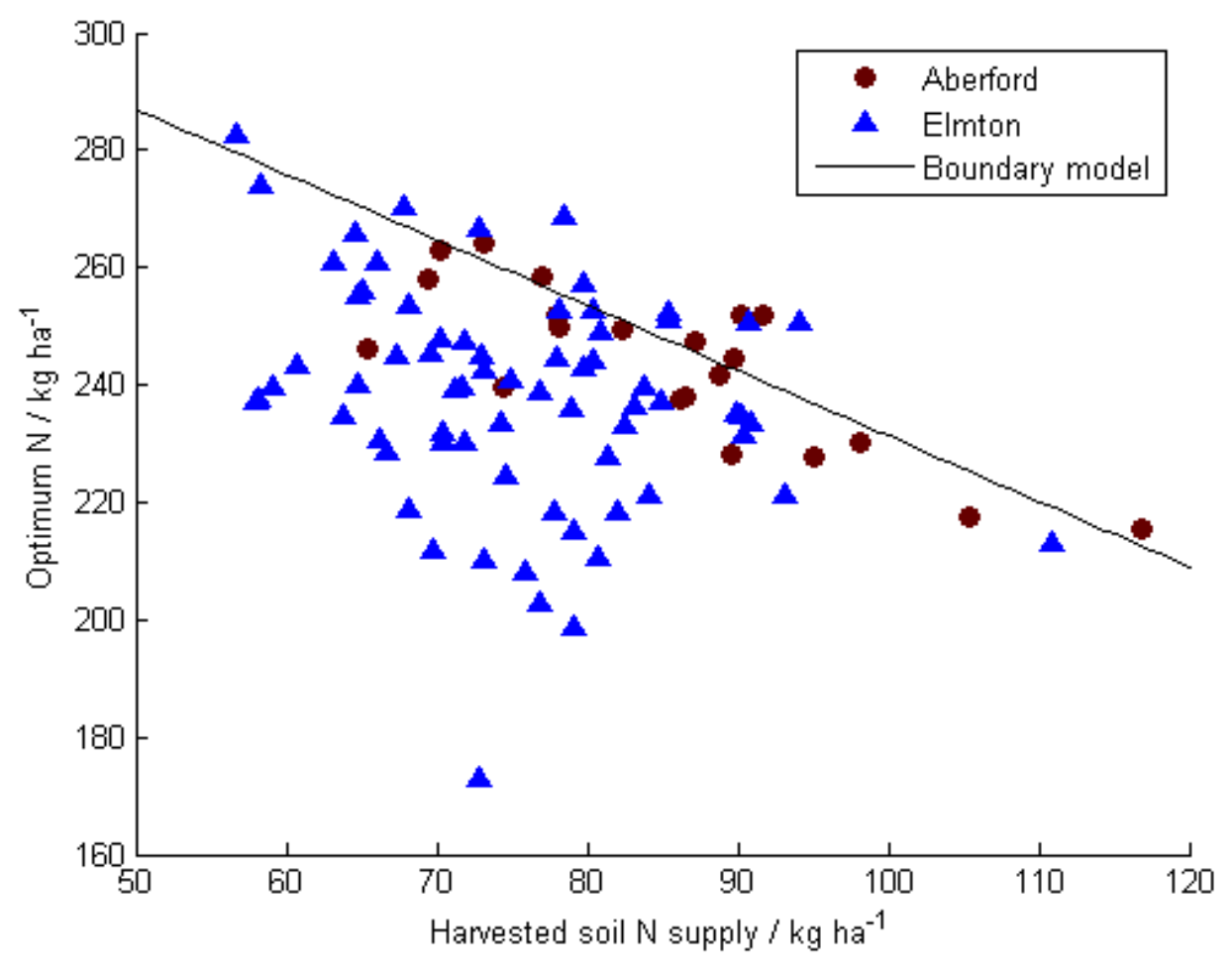

Fig. 6. 
a)

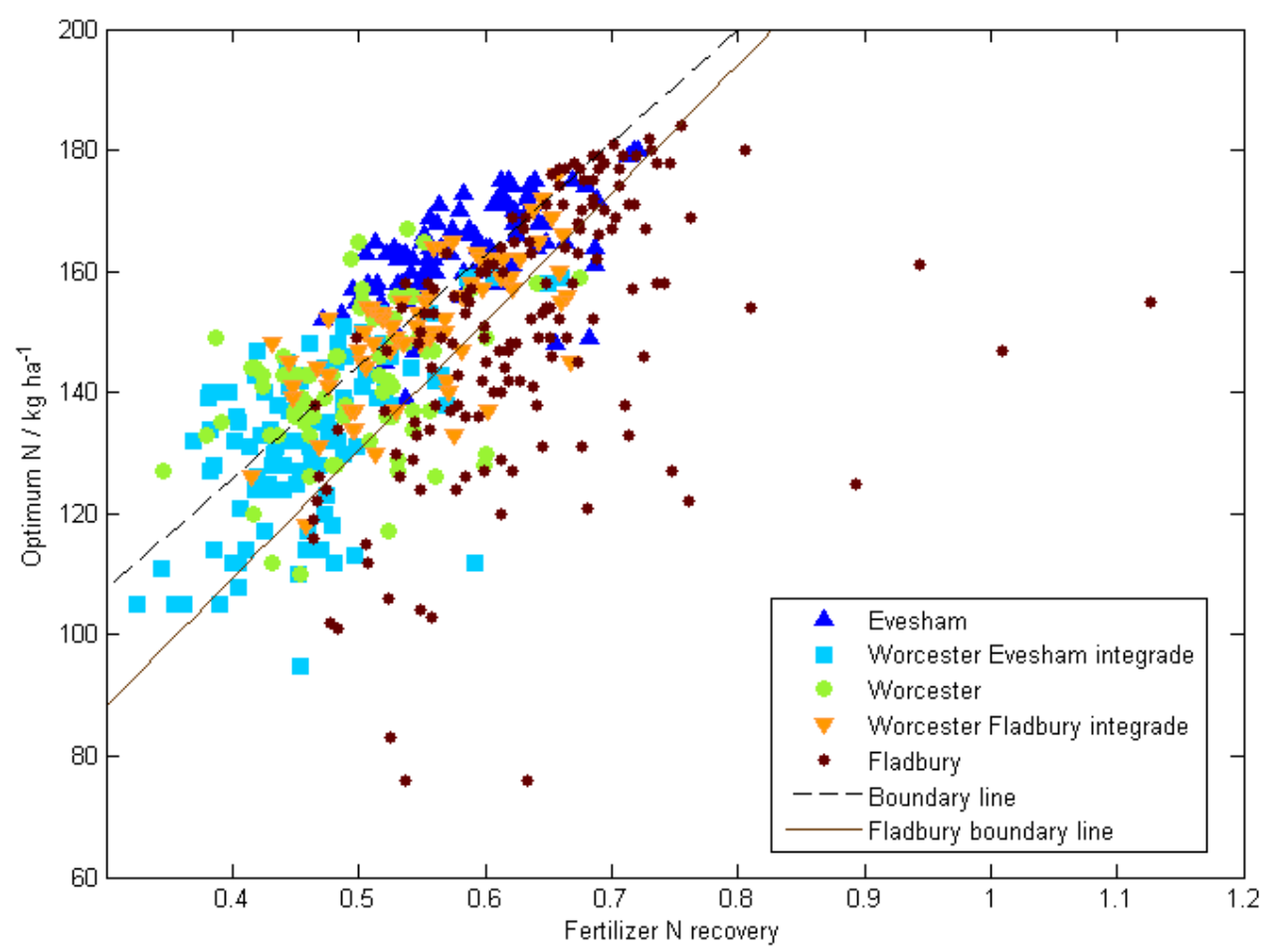

b)

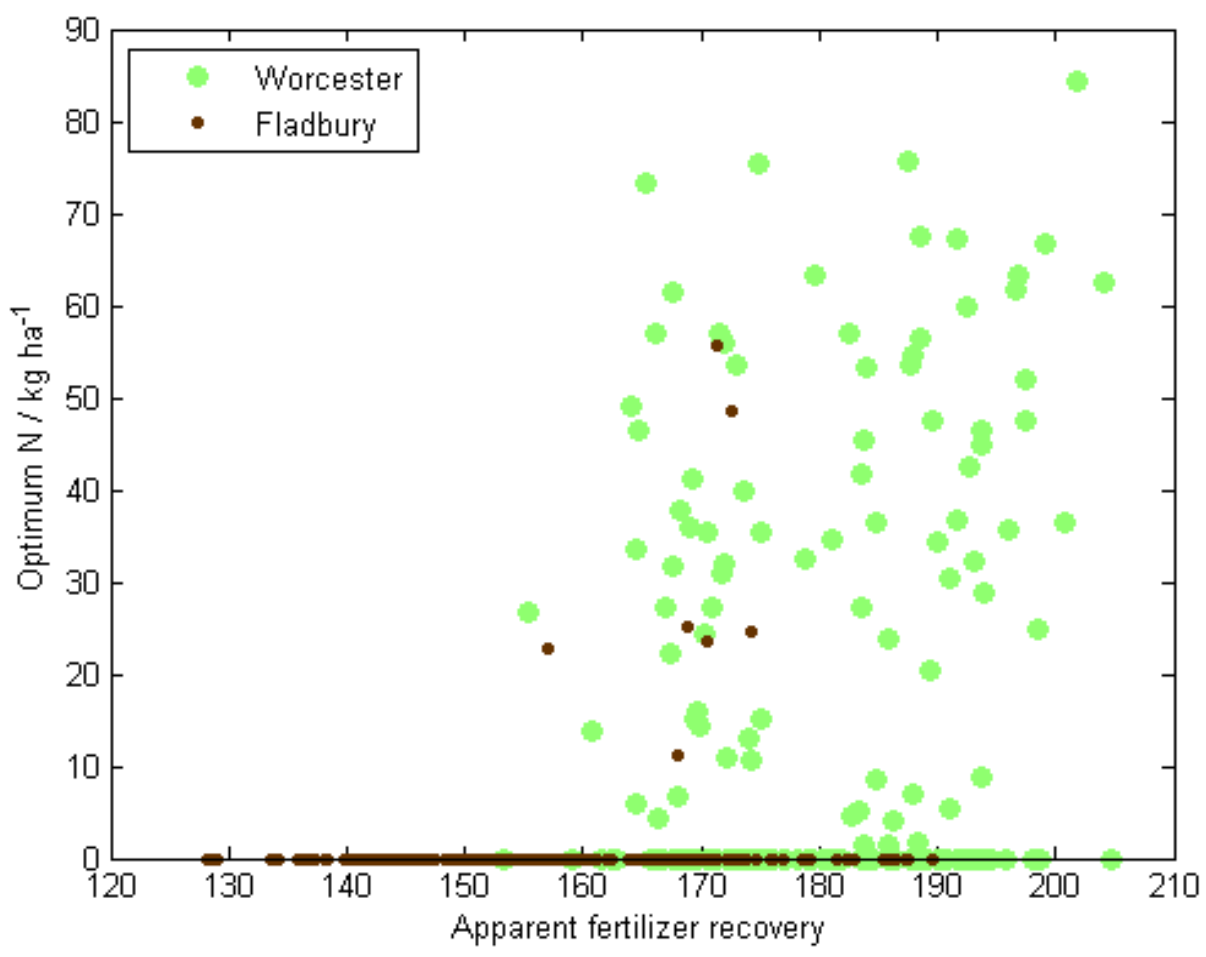


c)

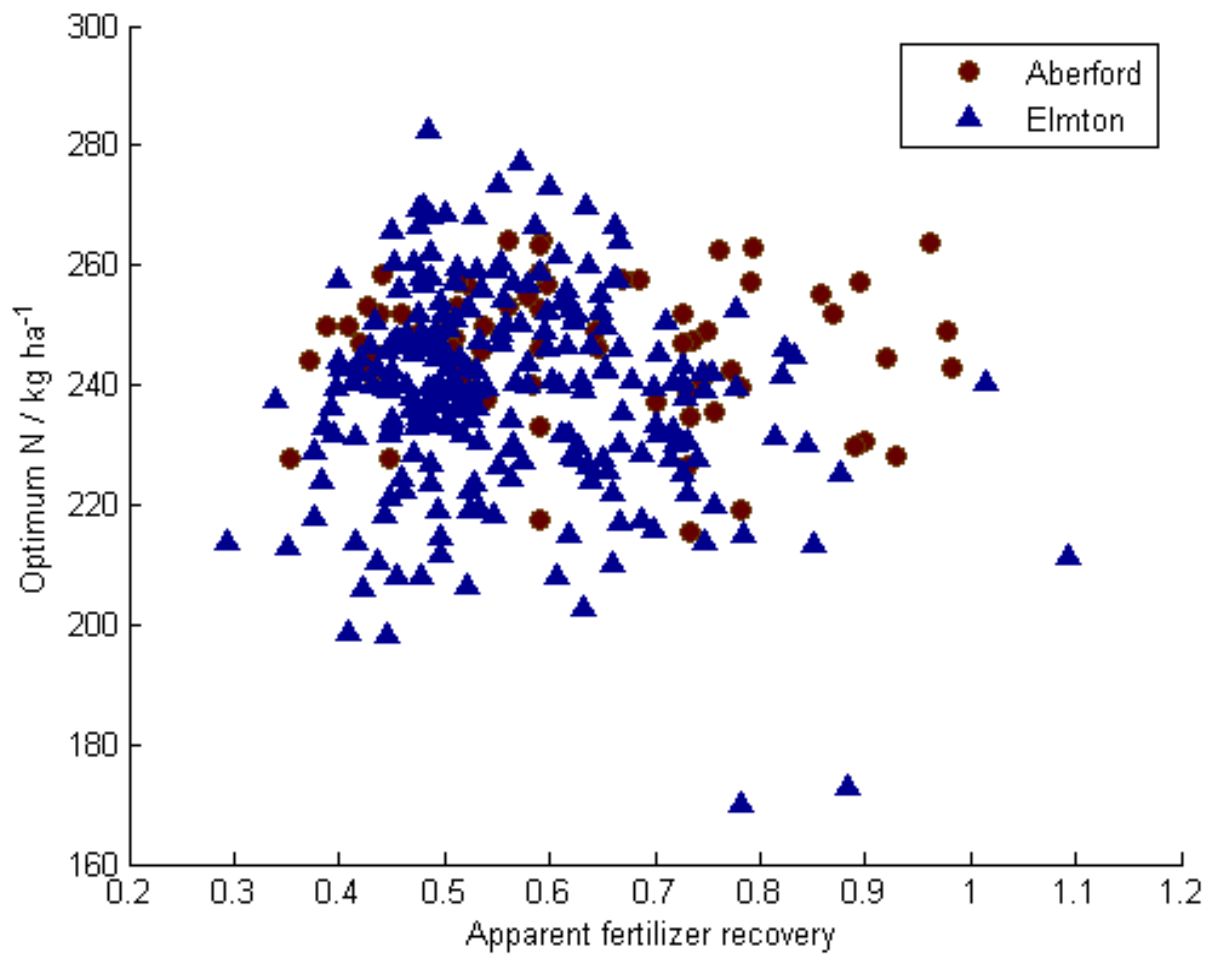

Fig. 7. 